\title{
Article \\ Evaluating Strategies to Improve Water Availability and Lateral Root Growth of Plants Grown in the Rice-Growing Lowlands of the Lower Mekong Basin
}

\author{
Carlos Ballester ${ }^{1, *}$, John Hornbuckle ${ }^{1}{ }^{(}$, Thavone Inthavong ${ }^{2}$, Vanndy Lim ${ }^{3}$, Jeffrey McCormick ${ }^{4}(0$, \\ Anika Molesworth ${ }^{1}$, Chantha Oeurng ${ }^{5}$, Wendy Quayle ${ }^{1}(0)$, Vang Seng ${ }^{6}$, Pheng Sengxua ${ }^{7}$, Vorachith Sihathep ${ }^{8}$, \\ Veasna Touch ${ }^{3}$, Camilla Vote ${ }^{9}$ and Philip Eberbach ${ }^{9}$
}

Citation: Ballester, C.; Hornbuckle, J. Inthavong, T.; Lim, V.; McCormick, J.; Molesworth, A.; Oeurng, C.; Quayle, W.; Seng, V.; Sengxua, P.; et al. Evaluating Strategies to Improve Water Availability and Lateral Root Growth of Plants Grown in the Rice-Growing Lowlands of the Lower Mekong Basin. Agronomy 2021, 11, 1929. https://doi.org/10.3390/ agronomy11101929

Academic Editor: Alejandro Galindo

Received: 13 September 2021

Accepted: 15 September 2021

Published: 26 September 2021

Publisher's Note: MDPI stays neutral with regard to jurisdictional claims in published maps and institutional affiliations.

Copyright: (c) 2021 by the authors. Licensee MDPI, Basel, Switzerland. This article is an open access article distributed under the terms and conditions of the Creative Commons Attribution (CC BY) license (https:/ / creativecommons.org/licenses/by/ $4.0 /)$.
1 Centre for Regional and Rural Futures (CeRRF), Deakin University, Research Station Road, Griffith, NSW 2680, Australia; j.hornbuckle@deakin.edu.au (J.H.); anikm@deakin.edu.au (A.M.); w.quayle@deakin.edu.au (W.Q.)

2 Research Centre for Climate Change Resilience in Agriculture, National Agriculture and Forestry Research Institute, Nongviengkham Village, Xaythany District, Vientiane 0106, Laos; inthavong.thavone@gmail.com

3 Cambodian Agricultural Research and Development Institute (CARDI), National Road No 3, Sangkat Prateah Lang, Khan Kambol, Phnom Penh 12000, Cambodia; vanndylim168@gmail.com (V.L.); veasna80@gmail.com (V.T.)

4 School of Agricultural and Wine Sciences, Charles Sturt University, Locked Bag 588, Wagga Wagga, NSW 2678, Australia; jmccormick@csu.edu.au

5 Institute of Technology of Cambodia (ITC), Russian Conf. Blvd., Phnom Penh 12000, Cambodia; chantha@itc.edu.kh

6 Department of Agricultural Land Resources Management, General Directorate of Agriculture, No. 54B/49F, Street 395-656, Toeuk Laak 3, Tuol Kork, Phnom Penh 12158, Cambodia; sengvangkh@gmail.com

7 Agricultural Land Use Planning Centre, Department of Agricultural Land Management, Ministry of Agriculture and Forestry, Vientiane 0101, Laos; phengysx@gmail.com

8 Phone Ngam Rice Research and Seed Multiplication Centre, Pakse 1600, Laos; vorachithsh@gmail.com

9 Graham Centre for Agricultural Innovation, Charles Sturt University, Pugsley Ave, Wagga Wagga, NSW 2678, Australia; Vote@environment.gov.au (C.V.); PEberbach@csu.edu.au (P.E.)

* Correspondence: cballester@deakin.edu.au

Abstract: Overcoming constraints that poorly structured lowland rice-growing soils of the Lower Mekong River Basin present for growing non-rice crops during the dry season would have a significant positive impact on the livelihood of smallholder farmers. This study investigated whether the use of soil organic amendments, bed architecture (conventional, flat and narrow) and water application methods (sprinkler, furrow and over-bed irrigation) could improve plant water availability in typical rice-growing soils of Cambodia and Laos by either improving the movement of water into beds or the growth of the root system. Five experiments were conducted over two dry seasons on peanut and maize grown in a bed/furrow system. Organic amendments assessed were rice straw, cow/goat manure, biochar, manure plus rice straw and biochar plus manure. Results showed that compared with conventional bed/furrow design, narrowing beds increased soil moisture availability for peanut, whilst higher grain yield and water productivity were achieved with sprinkler irrigation than furrow irrigation. Placing a layer of sub-surface straw within beds did not consistently enhance soil moisture or improve root development. The study showed that maize grown on soil amended with biochar plus cow manure under a furrow irrigation system and on rice straw under sprinkler irrigation produced yields above the average yield that models have simulated for maize grown on these soils. These findings present opportunities to enhance maize production on lowland soils across Cambodia and Laos. The contrary was observed for peanut production, which indicates that factors other than water might be detrimentally affecting crop yields.

Keywords: dry season; maize; peanut; water productivity; irrigation 


\section{Introduction}

It is estimated that agriculture provides livelihoods for approximately $60 \%$ of the population in the Lower Mekong River Basin (LMB) [1]. The LMB covers land of four south east Asian nations, Thailand, Laos, Cambodia and Vietnam, and is currently home to approximately 60 million people. Some $75-85 \%$ of the people from these countries are rural-based, poor and depend directly on water for food [2]. Among the countries through which the Mekong River passes, Cambodia and Laos have been identified by the United Nations World Food Programme as two of the most impoverished nations in southeast Asia, with high rates of poverty, food insecurity and poor nutrition, particularly amongst small landholders. Due to the tropical climate that characterizes the LMB with annual wet $(>2000 \mathrm{~mm})$ and dry cycles, smallholder production of rain-fed rice is the main agricultural activity in this region. Most of the rice production area $(80 \%)$ is concentrated in the lowlands of the LMB where there are limited opportunities for growing alternative crops to rice, particularly during the wet season.

Incorporation of higher value non-rice crops during the dry season in rotation with rice has the potential to significantly improve income, water productivity, human nutrition and food security in the lowland production systems [3]. The incorporation of these crops into the rotations of smallholder farms, along with increasing the agricultural production across the region, could be an important pathway for improving average household income and general standards of living.

Research aimed at investigating the productivity of dry-season crops in both Cambodia and Laos has indicated that these systems are subject to major production constraints, including drought and low soil fertility [3]. Lowland soils are typically sandy in texture and prone to hard setting, lacking in both organic matter and cation exchange capacity (CEC), acidic in the aerobic state and containing high levels of aluminum, particularly in the subsoil [4,5]. Recently, Ballester et al. [6] highlighted the poor lateral movement of water in these soils, which leads to inadequate refilling of the root zone, a particular limitation for the establishment of furrow-irrigated dry-season crop production in the region.

The use of soil organic amendments may enhance soil structure and increase its water holding capacity and fertility, particularly during the first season of amendment [7]. Research conducted in long-term experiments has shown that regular addition of organic amendment improves soil fertility and structural stability, enhances total organic $\mathrm{N}$ levels and reduces bulk density [8]. Addition of woody and other organic amendments have also shown potential to improve water holding capacity of soils [9]. The use of readily available and low-cost amendments such as rice husk biochar or manure compost has been proposed to enhance soil properties and increase agricultural productivity $[10,11]$. For example, research conducted by Mekuria et al. [12] on Acrisol soils showed that the use of organic and clay-based soil amendments increased soil properties and maize production in central Laos.

For dry-season crop production under bed/furrow systems, soil organic interventions could increase root access to water by either improving the lateral movement of water into beds or promoting the lateral expansion of roots that are otherwise limited in such compacted and physically strong soils. The main objective of this study was to use a set of experiments conducted over two dry seasons on typical rice-growing soils of the lowlands of Cambodia and Laos to investigate the effect of soil organic interventions, bed architecture and water application methods on water availability, belowground and aboveground biomass production and yield of peanut and maize. The experiments were conducted on maize (Zea mays Linnaeus) in Cambodia and peanut (Arachis hypogaea Linnaeus) in Laos, which are two of the major non-rice crops grown in these countries [13]. Using agronomic management, the lateral water movement constraint reported in Ballester et al. [6] may be overcome, which would provide major impact across large areas of south east Asia for increased dry season non-rice crop yields. 


\section{Materials and Methods}

\subsection{Study Site Locations}

The study was conducted during the 2016/17 and 2017/18 dry seasons (from December to April) at the Phone Ngam Rice Research Centre, PNG $\left(15^{\circ} 08^{\prime} 14.97^{\prime \prime} \mathrm{N}, 105^{\circ} 47^{\prime} 13.78^{\prime \prime} \mathrm{E}\right.$ elevation $101 \mathrm{~m}$ ), Pakse district, Champasak province in southern Laos and the Cambodian Agricultural Research and Development Institute, CARDI $\left(11^{\circ} 28^{\prime} 34.27^{\prime \prime} \mathrm{N}, 104^{\circ} 48^{\prime} 32.26^{\prime \prime} \mathrm{E}\right.$ elevation $17 \mathrm{~m}$ ) Kambol district, Phnom Penh city in Cambodia (Figure 1). More details about the location of the sites can be found in Ballester et al. (2019). Soil at these locations was a typical lowland rice-growing soil classified as Gleyic Acrisol based on the FAO/UNESCO classification [14]. At both sites, soil at $0-40 \mathrm{~cm}$ depth was predominantly sandy loam $(62.0 \%$ sand and $27.0 \%$ silt at CARDI, and $58.8 \%$ sand and $29.6 \%$ silt at PNG) with the presence of clay $(20 \%)$ increasing in the $40-60 \mathrm{~cm}$ soil layer. At CARDI, soil pH in 2016 pre-planting was 6.72 and 7.12 at $0-20 \mathrm{~cm}$ and $20-50 \mathrm{~cm}$ depth, respectively. At PNG, soil pH in 2016 pre-land preparation was 5.36 at $0-20 \mathrm{~cm}$ depth and averaged 5.91 in the 20-60 cm soil layer. More details regarding the physico-chemical properties of the soils at both sites can be found in Table 2 in Ballester et al. [6].

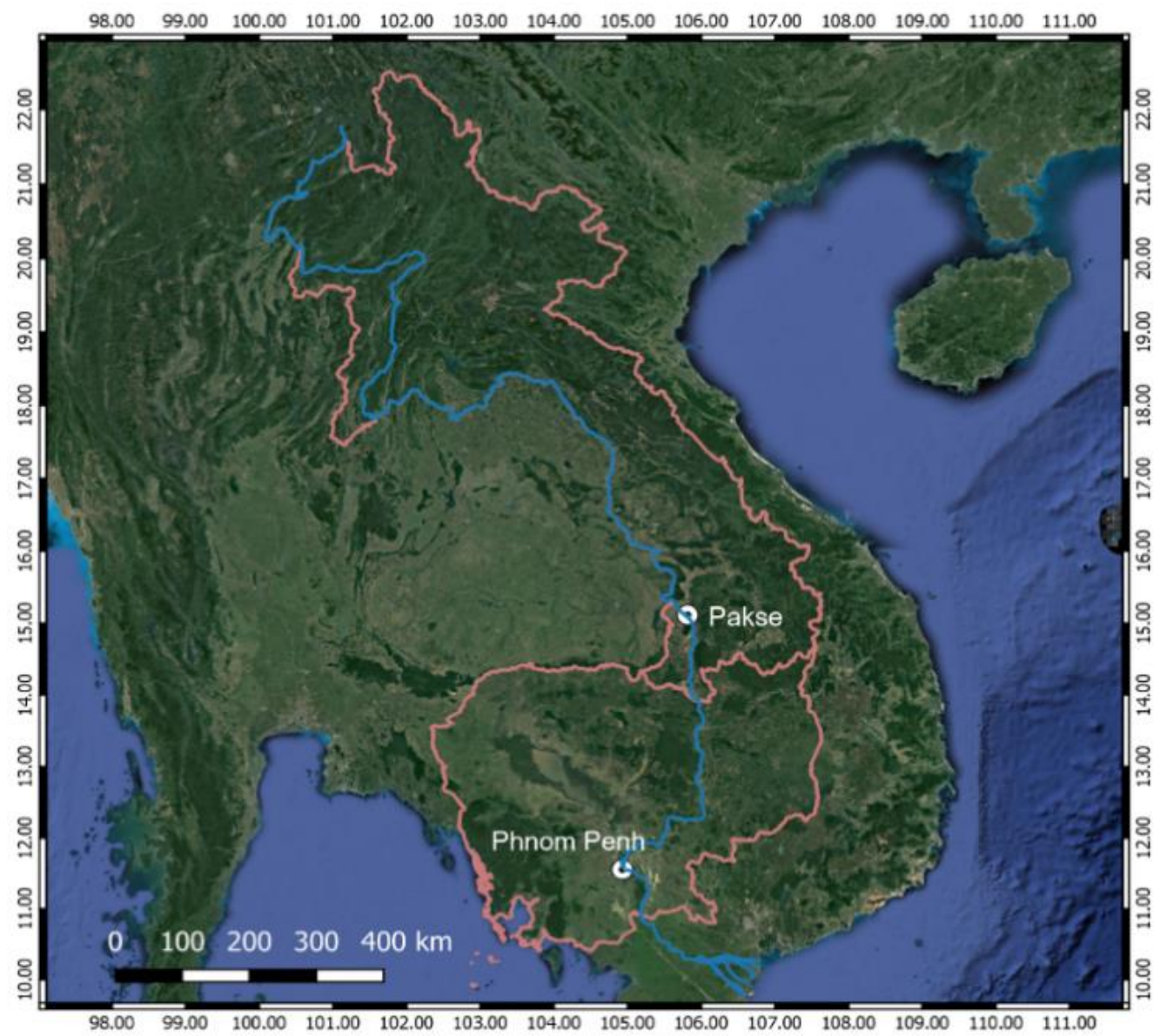

Figure 1. Location details of the countries of Pakse (Laos) and Phnom Penh (Cambodia), where the experiments were conducted, and the course of the Mekong River (blue line).

One experiment was conducted per site in the 2016/17 dry season. In the 2017/18 dry season, one experiment was conducted at CARDI while two parallel experiments were conducted at PNG. 


\subsection{Experiments Conducted in the 2016/17 Dry Season}

\subsubsection{Experiment 1}

Experiment 1 was conducted at PNG to investigate (i) the effect that fertilizer placement could have on crop nutrient availability caused by poor lateral water movement from furrows into the center of the beds, and (ii) the effect of different types of organic amendments on peanut yield. Fertilizer was placed in the middle of the beds (F1) and along the edge of the bed, slightly offset from the seeding row and below seeds (F2). The soil amendment treatments tested were: (C) control, no soil amendment, (SB) rice straw at $5 \mathrm{t} \mathrm{ha}^{-1}$ and $(\mathrm{M})$ surface spread cow/goat manure at $20 \mathrm{t} \mathrm{ha}^{-1}$. Manure was spread over the soil surface and incorporated into the soil during bed forming. Once beds were formed using a three-point linkage bed forming bar on a tractor (beds $0.30 \mathrm{~m}$ aside $0.25 \mathrm{~m}$ furrows), uncut rice straw was laid out in the depression formed in the center of each bed of the SB treatment and covered with soil recovered from the floor of the adjacent furrows. This created a buried subsurface residue layer at $\sim 0.10 \mathrm{~m}$ depth.

The experimental design was a three-by-two factorial randomized block design with three replicates. Figure 2 illustrates the distribution of the treatments and dimensions of the site and plots.

On 7 and 8 December 2016, seeds of the L23 variety of peanut were sown at $\sim 2.0 \mathrm{~cm}$ depth by hand along the edge of each bed in two rows at a spacing of $0.30 \mathrm{~m} \times 0.25 \mathrm{~m}$ and fertilizer (15:15:15 NPK) at $156 \mathrm{~kg} \mathrm{ha}^{-1}$ was banded at a depth of $\sim 3.0 \mathrm{~cm}$, offset and below the seeding depth. The site was hand-watered daily from sowing until 9 January 2017 when furrow irrigation commenced. Irrigation water had an average $\mathrm{pH}$ of 7.9 and an electrical conductivity (EC) of $0.07 \mathrm{dS} \mathrm{m}^{-1}$ for the season.

Average daily air temperature (Ta) during the $2016 / 17$ peanut growing season was $26.0^{\circ} \mathrm{C}$. Minimum and maximum Ta recorded were $21.9^{\circ} \mathrm{C}$ and $30.0^{\circ} \mathrm{C}$. Unseasonal rainfall events occurred on 21-28 January ( $\sim 326 \mathrm{~mm})$, on 3-14 February $(\sim 340 \mathrm{~mm})$ and on 16-25 March $(\sim 471 \mathrm{~mm})$ with the total rainfall over the season being $1171 \mathrm{~mm}$. Total $\mathrm{ET}_{\mathrm{o}}$ was $474 \mathrm{~mm}$. In the early crop stages, the crop was irrigated twice a week with an average total irrigation depth of $14 \mathrm{~mm}$ per plot and event. As the season progressed, irrigation frequency was adjusted to three days per week to account for the increasing evaporative demand and plant water requirements. The average cumulative total of irrigation water applied to each plot was $278 \mathrm{~mm}$.

\subsubsection{Experiment 2}

Experiment 2 was conducted at CARDI. The experiment was a four-by-two factorial randomized block design with three replicates (Figure 2). The main treatments applied were (C) control, no soil amendment, (SB) rice straw at $10 \mathrm{t} \mathrm{ha}^{-1}$ buried in beds as a part of bed forming, (SI) rice straw at $10 \mathrm{tha}^{-1}$ and $(\mathrm{B}+\mathrm{M})$ biochar mixed with cow manure at $10 \mathrm{tha}^{-1}$. Two inorganic fertilizer rates applied at sowing were also tested: (F1) $90 \mathrm{~N}, 60 \mathrm{P}_{2} \mathrm{O}_{5}, 30 \mathrm{~K}_{2} \mathrm{O}$ (Urea $47 \mathrm{~kg} \mathrm{ha}^{-1}$, diammonium phosphate (DAP) $130 \mathrm{~kg} \mathrm{ha}^{-1}$ and potassium chloride (KCl) $50 \mathrm{~kg} \mathrm{ha}^{-1}$ ), and (F2) $135 \mathrm{~N} ; 90 \mathrm{P}_{2} \mathrm{O}_{5} ; 45 \mathrm{~K}_{2} \mathrm{O}$ (Urea $70.5 \mathrm{~kg} \mathrm{ha}^{-1}$, DAP $\left.195 \mathrm{~kg} \mathrm{ha}^{-1}, \mathrm{KCl} 75 \mathrm{~kg} \mathrm{ha}^{-1}\right)$. In the SI plots, rice straw was spread and incorporated into the soil with a rotary hoe before bed forming. In the SB and B + M treatments, rice straw and biochar plus manure, respectively, were banded as part of the bed forming process. Fertilizers were banded in the middle of the bed in the F1 and F2 treatments.

On 17 January 2017, maize (variety CM1) was sown with a plant and row spacing of $0.30 \mathrm{~m}$ and $0.65 \mathrm{~m}$, respectively. Germination success was low due to untimely rainfall that disrupted beds. The control treatment had the greatest germination success $(48.9 \%)$, followed by B + M (36.75\%), SI $(35.6 \%)$ and SB (31.4\%) treatments. Locations where germination had not occurred were re-sown on 25 January 2017 . The site was hand-watered until two weeks after emergence when the crop was furrow-irrigated. 


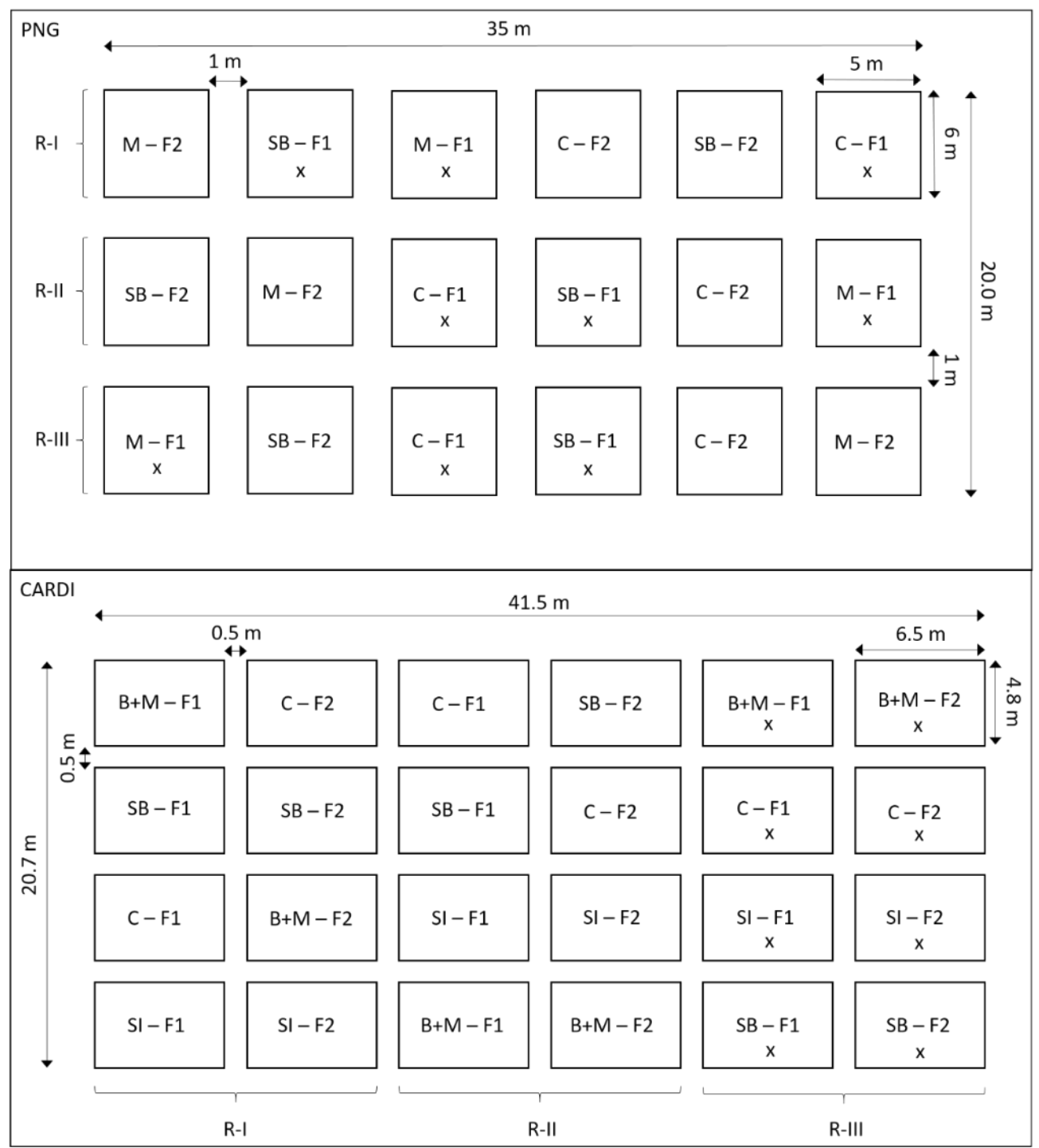

Figure 2. Experimental layout during the 2016/17 dry season of experiment 1 at PNG (top) and experiment 2 at CARDI (bottom). Location of the soil water tension sensors in each experiment is indicated with the symbol " $\mathrm{x}$ ". $\mathrm{C}=$ control; $\mathrm{SB}=$ rice straw buried; $\mathrm{M}=$ manure; $\mathrm{B}+\mathrm{M}=$ biochar plus manure; $\mathrm{SI}=$ rice straw incorporated. F1 and F2 in the experiment at PNG indicate fertilizer placed in the middle of the bed and along the edge of the bed, respectively. At CARDI, F2 plots were fertilized with 1.5 times the rate applied in F1 plots.

During the 2016/17 maize growing season at CARDI (from 17 January to 10 April 2017), daily average Ta ranged from $24.5^{\circ} \mathrm{C}$ to $31.9^{\circ} \mathrm{C}$ and relative humidity from $55.7 \%$ to $98.0 \%$. Total $\mathrm{ET}_{\mathrm{o}}$ and rainfall for the growing season were $386.1 \mathrm{~mm}$ and $124 \mathrm{~mm}$, respectively. Most of the rainfall $(75 \mathrm{~mm})$ was recorded in a rain event at the end of the growing season which delayed harvest until 10 April 2017. The average cumulative total of irrigation water applied to each plot was $177 \mathrm{~mm}$.

\subsection{Experiments Conducted in the 2017/18 Dry Season}

\subsubsection{Experiments 3 and 4}

Experiment 3 and 4 were conducted at PNG. Experiment 3 consisted of a control (unamended) treatment $(\mathrm{C})$ and two soil organic amendment treatments: incorporated cow manure at $20 \mathrm{tha}^{-1}(\mathrm{M})$ and incorporated cow manure at $20 \mathrm{t} \mathrm{ha}^{-1}$ plus straw at $5 \mathrm{tha}^{-1}$ $(\mathrm{M}+\mathrm{SB})$. The experiment had a single factor randomized block design and consisted of 
three replicates (Figure 3). Soil amendment treatments were applied as indicated for the previous growing season.

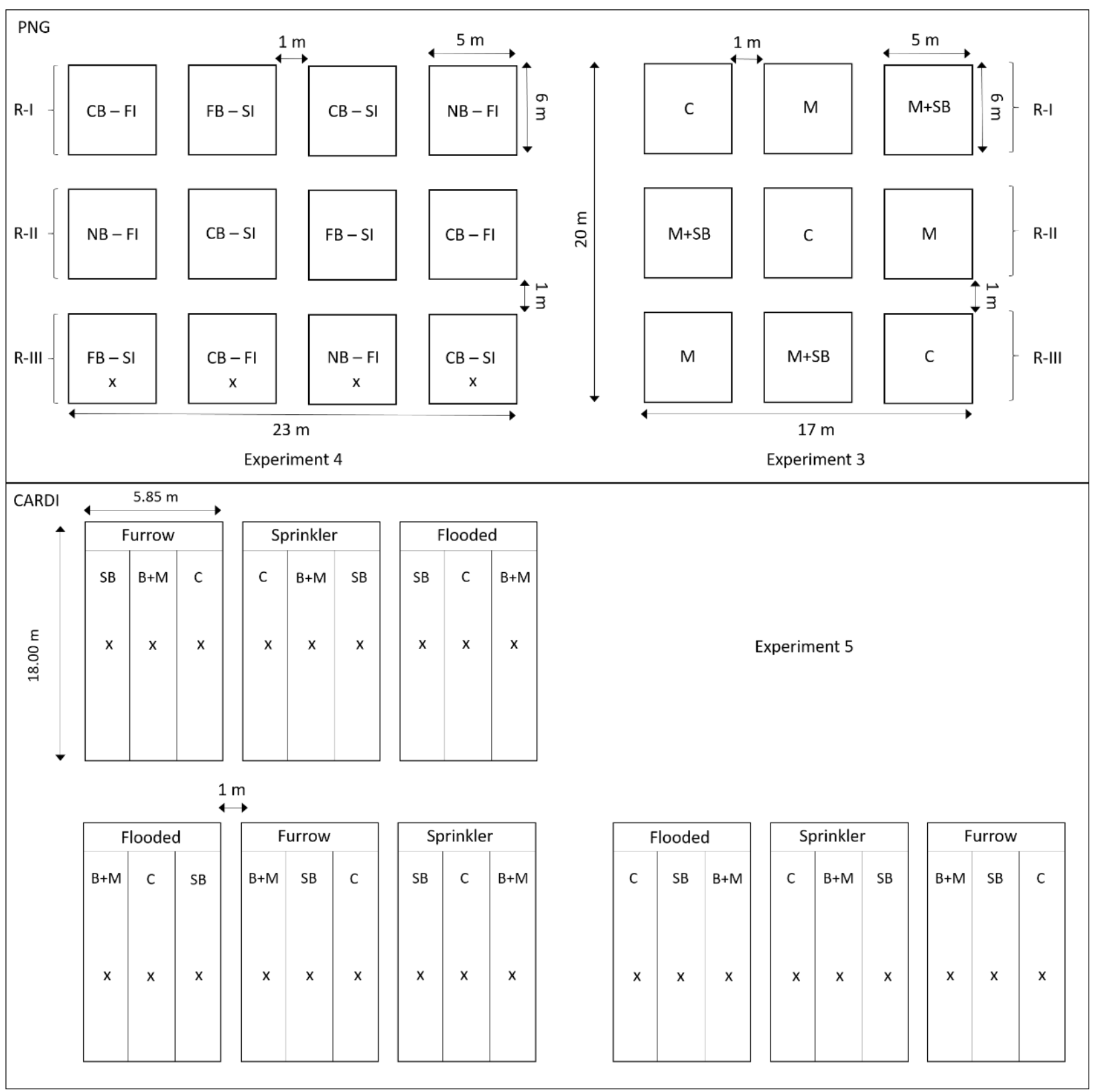

Figure 3. Experimental layout during the $2017 / 18$ dry season at PNG (top) and CARDI (bottom). Location of the soil water tension sensors at both sites is indicated with the symbol " $\mathrm{x}$ ". $\mathrm{C}=$ control; $\mathrm{M}=$ manure; $\mathrm{M}+\mathrm{SB}=$ manure plus rice straw buried; $\mathrm{CB}-\mathrm{FI}$ = conventional bed furrow system with furrow irrigation; FB - SI = flat bed with sprinkler irrigation; NB $\mathrm{FI}=$ narrow bed with furrow irrigation; $\mathrm{CB}-\mathrm{SI}=$ conventional bed furrow system with sprinkler irrigation; $\mathrm{SB}=$ rice straw buried; $\mathrm{B}+\mathrm{M}=$ biochar plus cow manure.

Experiment 4 was a complete randomized block design combining three bed structures (conventional bed/furrow, flat bed and narrow bed) with two irrigation treatments (furrow irrigation and sprinkler irrigation) (Figure 3). Table 1 describes the treatments applied in experiments 3 and 4 . Beds in treatments CB-FI, CB-SI and NB-FI were formed using a bed making equipment that was adjusted to form narrower beds in the case of the NB-FI treatment. For the flat bed treatment (FB-SI), once the soil had been ploughed, a bund was constructed surrounding the bay to retain irrigation water. 
Table 1. Treatments applied in the experiments 3 and 4 conducted during the 2017/18 dry season.

\begin{tabular}{|c|c|c|}
\hline Treatment & $\begin{array}{c}\text { Soil Amendment/Bed } \\
\text { Architecture }\end{array}$ & Irrigation Method \\
\hline \multicolumn{3}{|l|}{$\begin{array}{l}\text { Experiment 3: } \\
\text { soil amendments }\end{array}$} \\
\hline $\mathrm{C}$ & None & Furrow irrigation \\
\hline M & manure at $20 \mathrm{t} \mathrm{ha}^{-1}$ & Furrow irrigation \\
\hline $\mathrm{M}+\mathrm{SB}$ & $\begin{array}{c}\text { manure at } 20 \mathrm{tha}^{-1}+\text { buried } \\
\text { straw at } 5 \mathrm{t} \mathrm{ha}^{-1}\end{array}$ & Furrow irrigation \\
\hline \multicolumn{3}{|l|}{$\begin{array}{l}\text { Experiment } 4: \\
\text { bed architectures and } \\
\text { irrigation methods }\end{array}$} \\
\hline CB-FI & Conventional bed and furrow * & Furrow irrigation \\
\hline FB-SI & Flat bed & $\begin{array}{l}\text { Handheld sprinkler } \\
\text { irrigation }\end{array}$ \\
\hline CB-SI & Conventional bed and furrow * & $\begin{array}{l}\text { Handheld sprinkler } \\
\text { irrigation }\end{array}$ \\
\hline NB-FI & Narrow bed and furrow $\mathrm{y}$ & Furrow irrigation \\
\hline
\end{tabular}

Peanut (variety L23) were sown on 25 December 2017 in a similar manner to the previous season. Basal fertilizer was banded in the middle of the bed following the F1 strategy of experiment 1.

Over the 2017/18 peanut growing season (25 December 2017 to 5 April 2018), minimum and maximum Ta recorded were $21.0^{\circ} \mathrm{C}$ and $31.7^{\circ} \mathrm{C}$, respectively. In contrast with the 2016/17 dry season, and as typically observed for the geographic region where the study was conducted, rainfall was scarce and only $21.6 \mathrm{~mm}$ were recorded over the growing season.

Plots from experiments 3 and 4 were hand watered daily for two weeks after which the farm method of irrigation were established on 10 January 2018. Averaged amount of water supplied in experiment 3 was $400 \mathrm{~mm}$. In experiment 4 , due to differences in the delivery rate between outlets in the furrow irrigation system and the hose used for the sprinkler irrigation, the total amount of water applied in sprinkler-irrigated plots was $75 \%$ of that applied to furrow-irrigated plots. On average, furrow-irrigated and sprinkler-irrigated plots received a total amount of irrigation water of $414.0 \mathrm{~mm}$ and $311.8 \mathrm{~mm}$, respectively.

\subsubsection{Experiment 5}

Experiment 5 was conducted at CARDI, where three irrigation treatments (furrow irrigation, sprinkler irrigation and over-bed irrigation) were tested in combination with three soil amendment treatments: (C) no amendment, (SB) rice straw banded at $10 \mathrm{tha}^{-1}$ after bed forming and $(B+M)$ biochar plus cow manure at $10 \mathrm{tha}^{-1}$. The experimental layout was a split plot design where irrigation was the main plot factor arranged in a randomized complete block design with three replicates and soil organic amendment was the second factor distributed as subplots within the irrigation treatments (Figure 3). In the over-bed irrigation treatment, water was applied through furrows, but plots were designed to allow water to reach an over-bed level to ensure water reached the center of the beds. To avoid waterlogging conditions in this treatment due to water ponding in the plots for an extended time period, plots were drained $30 \mathrm{~min}$ after each irrigation event. Each irrigation plot consisted of nine beds (three per soil amendment treatment). Maize was sown at a plant and row spacing of $0.25 \mathrm{~m}$ and $0.65 \mathrm{~m}$.

Basal fertilizer was applied at sowing in the middle of the beds in all treatments. $\mathrm{P}$ and $\mathrm{K}$ crop requirements were applied as diammonium phosphate and $\mathrm{KCl}$ upfront while $\mathrm{N}$ was split in three equal applications of urea throughout the growing season (23 January, 19 February and 13 March 2018) to provide a total 184-90-45 NPK kg ha ${ }^{-1}$. The 
site was hand-watered every one or two days until emergence and then irrigated with the corresponding irrigation method.

Average daily Ta for the maize growing season was $28.0^{\circ} \mathrm{C}$ with a minimum daily temperature of $18.1^{\circ} \mathrm{C}$ recorded on 7 February 2018 and a maximum daily temperature of $37.6^{\circ} \mathrm{C}$ reached later in the season on 17 April 2018. Total $\mathrm{ET}_{\mathrm{O}}$ and rainfall values recorded during this period were $544 \mathrm{~mm}$ and $39 \mathrm{~mm}$, respectively. Average total water applied to the furrow and sprinkler-irrigated treatments (not monitored in the over-bed irrigation) was $236 \mathrm{~mm}$ and $209 \mathrm{~mm}$, respectively.

\subsection{Soil Water Tension}

Soil water tension was monitored in all the experiments with the exception of experiment 3 by means of one to three Watermark sensors (Model 200SS, Irrometer Company inc., California USA) installed in the middle of the central beds at $15 \mathrm{~cm}$ depth (Figures 2 and 3 ). Sensors were connected to either 900M Irrometer dataloggers (Irrometer Company inc., California, USA) or Wi-Field loggers (Goanna Telemetry, Goondiwindi, QL, Australia), which sent data hourly to a cloud-based data storage, processing and internet interface in real time (Brinkhoff et al., 2017).

\subsubsection{Aboveground and Belowground Biomass Development}

Ground canopy cover (GCC) was monitored across the growing season in experiments 1 (on 11 dates), 3 (on 20 dates) and 4 (on 17 dates) using the app Canopeo [15]. Measurements were taken at three randomly selected locations within each plot to determine the average value for each treatment.

Aboveground biomass was measured in all the experiments 3-4 times across the season using at least six plants per amendment treatment. In experiments 1, 2, 3 and 5 , belowground biomass was also assessed. These measurements were taken from the vegetative stage to harvest in peanut and from flowering to harvest in maize. In experiment 1, part way through the excavation, the roots of each plant were photographed in situ as an indicator of root system structure and then once the rest of the root system had been excavated and cleaned of soil, the root system of the plant was carefully laid out with a reference scale and photographed again. At a later stage, using the photographs, the length of roots in each plant in the 5-15 cm deep soil layer were measured manually. For experiments 1, 2, 3 and 5, after cleaning, aboveground and belowground parts were separated, and fresh weight recorded. Each sample was oven dried at $70{ }^{\circ} \mathrm{C}$ for $48 \mathrm{~h}$, reweighed to obtain root dry weight, shoot dry weight, shoot-to-root ratio and width of the root system. In experiment 3 , the root system of each plant was sectioned into three layers $(0-5 \mathrm{~cm}, 5-15 \mathrm{~cm}$ and $>15 \mathrm{~cm}$ depth) and roots from the 5-15 cm soil layer individually measured for length. Aboveground and belowground measurements in experiment 5 were only conducted in the furrow-irrigated treatment.

\subsubsection{Yield and Water Productivity}

Peanut were harvested on 4 April in 2017 and on 30 March in 2018. Pods from each plot were harvested and fresh weight determined. Dry pod weight and dry grain weight were determined by oven-drying a $1 \mathrm{~kg}$ sub-sample at $\sim 70{ }^{\circ} \mathrm{C}$ for $48 \mathrm{~h}$.

Harvest in the maize experiments occurred on 10 April in 2017 and on 19 April in 2018. Plant samples were taken within each plot from a sampling area of $8.45 \mathrm{~m}^{2}$ (52 plants) and fresh cob weight and grain yield at $14 \%$ moisture determined.

Water productivity was calculated as the ratio between grain yield and total amount of irrigation water applied $\left(\mathrm{kg} \mathrm{m}^{-3}\right)$.

\subsubsection{Statistical Analysis}

One-way and two-way analyses of variance (ANOVA) were used to determine whether there was a statistically significant difference in crop development, yield and water productivity among treatments. Significant differences between treatments was 
tested using the least significant difference (LSD) post-hoc test with the level of significance set at $p \leq 0.05$.

\section{Results and Discussion}

\subsection{Experiment 1 (PNG 2016-17)}

Average values of soil water tension for each amendment treatment over the growing season are depicted in Figure 4. Control and amendment treatments responded similarly to irrigation and environmental conditions. The soil remained relatively wet during the time when the crop was hand watered and for two weeks after the establishment of furrow irrigation, until around the time of first flower emergence (18 January 2017; 43 days after sown, DAS). From that time, soil dried rapidly with minimal response to irrigation modifications (three irrigation events per week) or rainfall events. During February, the SB treatment (rice straw buried) retained a higher level of moisture compared to the other treatments. The apparent lower values of soil water tension in the SB treatment than in the other treatments could be the result of the buried straw layer intercepting the upward flux of water from the deeper soil, reducing its loss by evaporation. Only for the period from 16 to 25 March 2017 when significant rainfall events occurred $(471 \mathrm{~mm})$ did soil water tension in all treatments return to values close to zero, indicative of a saturated soil. The lack of response of the sensors to irrigation highlights the severity of the soil physical constrains to lateral movement of water in these rice-growing soils reported in Ballester et al. [6].

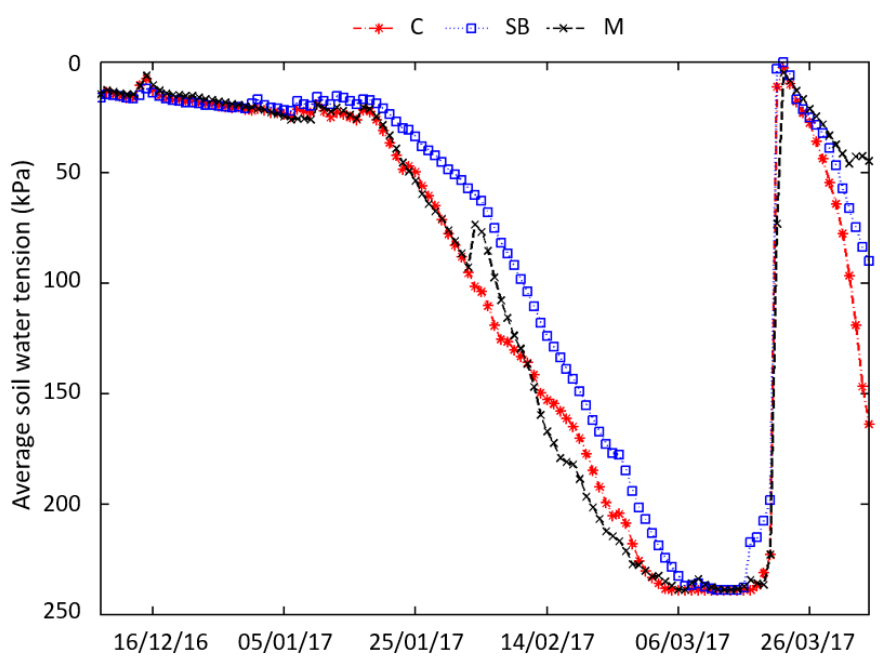

Figure 4. Average soil water tension for the amendment treatments in the 2016/17 dry season: (C) no soil amendment, (SB) rice straw at $5 \mathrm{tha}^{-1}$ buried in beds as a part of bed forming and (M) surface spread cow and goat manure at $20 \mathrm{t} \mathrm{ha}^{-1}$ before bed forming.

A significantly greater GCC was observed in the treatment amended with manure (M) than in the C and SB in the measurements from 9 January to 13 February 2017 and the last measurement date (Figure 5a). Aboveground biomass measurements also indicated that manure application promoted biomass production in comparison to the addition of rice straw or no addition of organic matter in the early, mid-season although differences among treatments were not apparent at harvest (Table 2). This result is not surprising as the Mekong alluvial sandy loam soils typically have negligible levels of organic matter and clay, and very low CEC [16]. This makes these soils dependent on fertilizers for most nutrients to drive production. The application of cow manure at $5 \mathrm{tha}^{-1}$ in the $\mathrm{M}$ treatment in addition to the synthetic fertilizer at sowing most likely provided the crop with nutrients such as $\mathrm{P}$ and $\mathrm{S}$ (less likely $\mathrm{N}$ due to the crop $\mathrm{N}$-fixing capacity) otherwise scarce in these soils. At harvest, there was a significant interaction between organic amendment and fertilizer placement on peanut biomass, which indicated peanut aboveground biomass to be less responsive to organic amendment when starter fertilizer was added in close 
proximity to the sowing row (F2) (Table 3). This is probably the result of more optimal placement of fertilizer to meet plant requirement. Fertilizer placement did not influence GCC (Figure 5b).
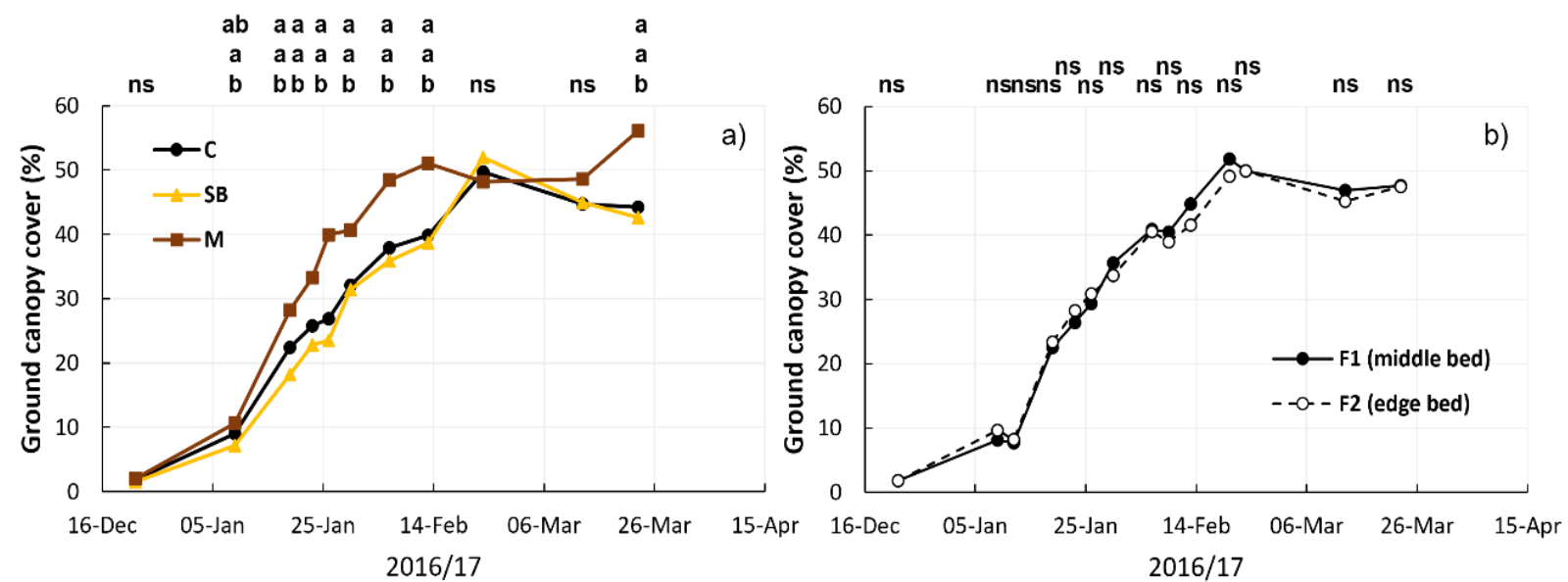

Figure 5. Average percentage of ground canopy cover of plants from the (a) soil amendment treatments: (no amendment (C), rice straw banded (SB) and manure (M)), and (b) fertilizer treatments tested in experiment 1 during the 2016/17 growing season. Different letters within a measurement date indicate statistically significant differences $(p<0.05)$ between treatments. "ns" denotes not statistically significant differences. The order of the letters from top to bottom correspond with the order in which treatments are presented in the legend of each graph.

Table 2. Two-way ANOVA for the effects of soil amendments and fertilizer placement on aboveground biomass of peanut $\left(\mathrm{t} \mathrm{ha}^{-1}\right)$ in experiment 1 .

\begin{tabular}{cccc}
\hline Aboveground Biomass & Flowering & Full Pod & Harvest \\
\hline Soil amendment & $*$ & $*$ & $\mathrm{~ns}$ \\
C & $2.75 \mathrm{a}$ & $5.33 \mathrm{a}$ & 7.37 \\
SB & $2.51 \mathrm{a}$ & $5.22 \mathrm{a}$ & 7.66 \\
M & $4.42 \mathrm{~b}$ & $6.44 \mathrm{~b}$ & 7.34 \\
Fertilizer placement & $\mathrm{ns}$ & $\mathrm{ns}$ & $\mathrm{ns}$ \\
F1 & 3.32 & 5.50 & 7.41 \\
F2 & 3.13 & 5.83 & 7.51 \\
Amendment X Fertilizer & $\mathrm{ns}$ & $\mathrm{ns}$ & $*$ \\
\hline
\end{tabular}

"ns" denotes not statistically significant differences while "**" indicates significant differences at $p \leq 0.05$. Different letters within a column denote significant differences between treatments. $\mathrm{C}=$ Control; $\mathrm{SB}=$ straw buried; $\mathrm{M}$ (manure).

Table 3. Effects of soil organic amendment and fertilizer placement on pod and peanut grain yield (t/ha).

\begin{tabular}{ccc}
\hline Yield (t/ha) & Pod & Grain \\
\hline Soil & $* *$ & $*$ \\
C & $2.03 \mathrm{a}$ & $1.07 \mathrm{a}$ \\
SB & $1.45 \mathrm{~b}$ & $0.77 \mathrm{~b}$ \\
M & $1.68 \mathrm{ab}$ & $0.87 \mathrm{ab}$ \\
Fertilizer & $\mathrm{ns}$ & $\mathrm{ns}$ \\
F1 & 1.71 & 0.91 \\
F2 & 1.72 & 0.89 \\
Soil:Fertilizer & $*$ & $\mathrm{~ns}$ \\
\hline
\end{tabular}

ns denotes not significant; ${ }^{*}$ significant at $p \leq 0.1{ }^{* *}$ significant at $p \leq 0.05$. Different letters within a column denote significant differences between treatments (Tukey-Kramer).

Plant sampling for the belowground assessment revealed that peanut root system was typically shallow $(15-35 \mathrm{~cm}$ depth) with lateral roots radiating out up to $60 \mathrm{~cm}$. Similar to 
the results presented in Table 2, dry weight of shoots and roots in the $M$ treatment appeared to be greater than in C and SB at maturity (22 March 2017) (Figure 6a,b). This, however, was not confirmed by the statistical analysis that did not detect significant differences between amendment or fertilizer treatments at any of the three sampling dates.
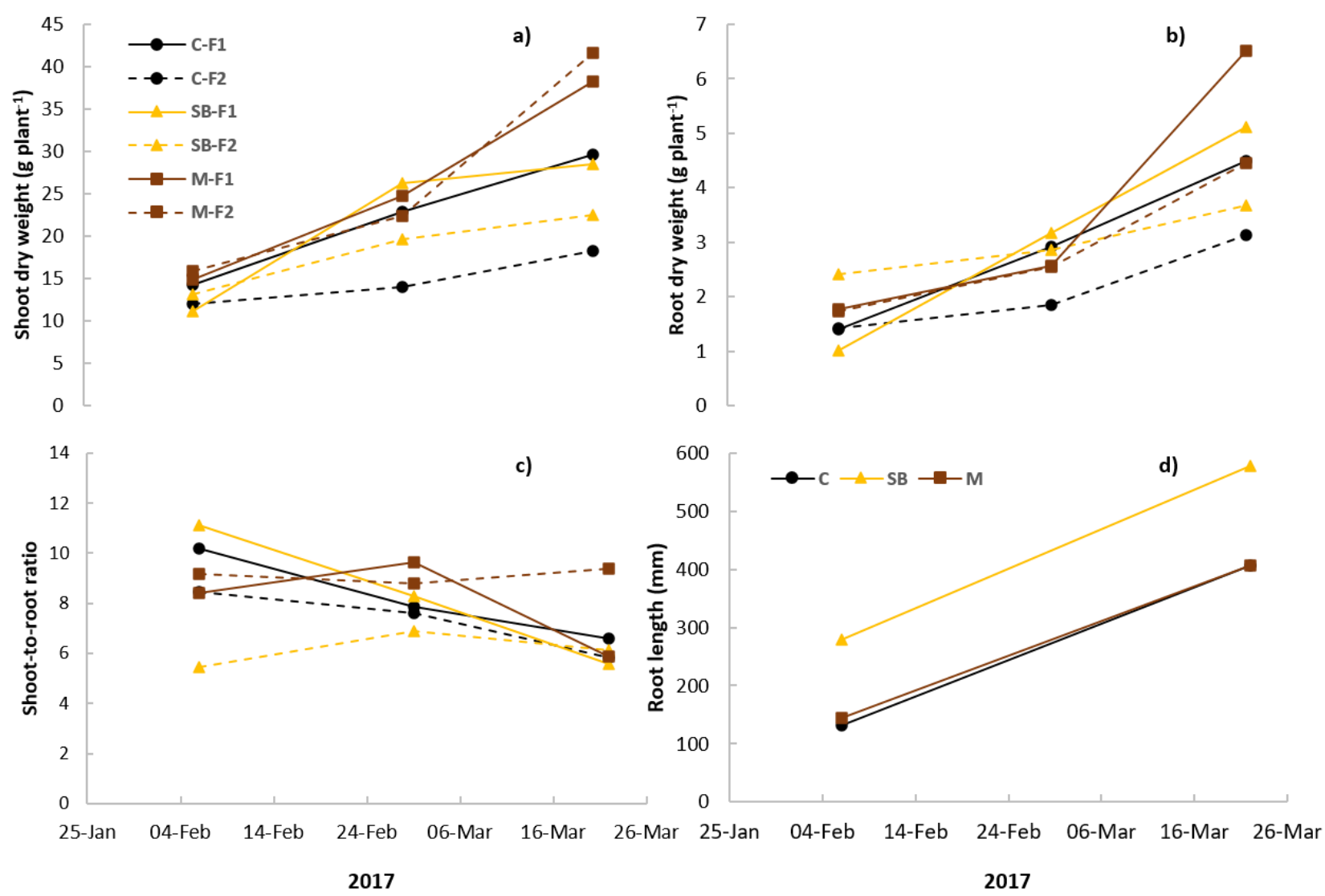

Figure 6. Biomass expressed in dry weight $\left(\mathrm{g} \mathrm{plant}^{-1}\right)$ of shoots (a), roots (b) and shoot-to-root ratio (c) as a function of organic amendments and fertilizer placement at vegetation (6 February 2017), mid-reproductive (1 March 2017) and maturity (22 March 2017) stages of the crop in the 2016/17 dry season. Average total length of lateral roots in the amendment treatments for the top $5-15 \mathrm{~cm}$ is also presented (d). No statistically significant differences were detected between treatments at any sampling date.

The partitioning of shoot and root carbohydrate at each sampling date consistently maintained a ratio of $\sim 8: 1$ for the three sampling periods indicating that none of the treatments altered the ratio of biomass partitioning in favor of roots (Figure $6 \mathrm{c}$ ). Nevertheless, the length of subsurface $(5-15 \mathrm{~cm}$ depth) lateral roots measured at the first and third sampling dates was statistically $(p<0.05)$ greater in the SB than in the C and M treatments (Figure 6d). Observations made at both sampling dates indicated that roots in the SB treatment appeared not to populate the buried straw layer as it was expected but instead, populated the interface between the straw layer and the soil layer either above or below the buried rice straw layer.

Although no differences in biomass were observed between treatments at harvest, the $C$ treatment produced significantly $(p<0.05)$ more pod and grain yield than SB (Table 3 ). No statistically significant differences were observed between the $C$ and $M$ treatments. The reduction in grain yield associated with the buried straw treatment (SB) could be due to the induced nutrient deficiency that could occur in soil due to the breakdown of the high $\mathrm{C}: \mathrm{N}$ rice straw. Placement of the fertilizer in relation to the crop at sowing did not influence yield and thus it was not further studied in the subsequent dry growing season. 


\subsection{Experiment 2 (CARDI 2016/17)}

Drier soil was monitored in beds than in furrows in all the treatments (Figure 7a,b). Comparison of the soil water tension in beds among treatments showed that SI and particularly the $\mathrm{B}+\mathrm{M}$ treatment retained a higher level of soil moisture during most of the growing season than the other two treatments (Figure 7a). Soil water tension was generally $>30 \mathrm{kPa}$ during the first half of the season. In early March, the soil tension differential between the furrows and beds was minimized in the $\mathrm{B}+\mathrm{M}$ treatment. This was in contrast to the treatments amended with rice straw (SI and SB), which were intended to promote lateral hydraulic conductivity. This result indicates that treatment $\mathrm{B}+\mathrm{M}$ was more effective in allowing lateral water movement.

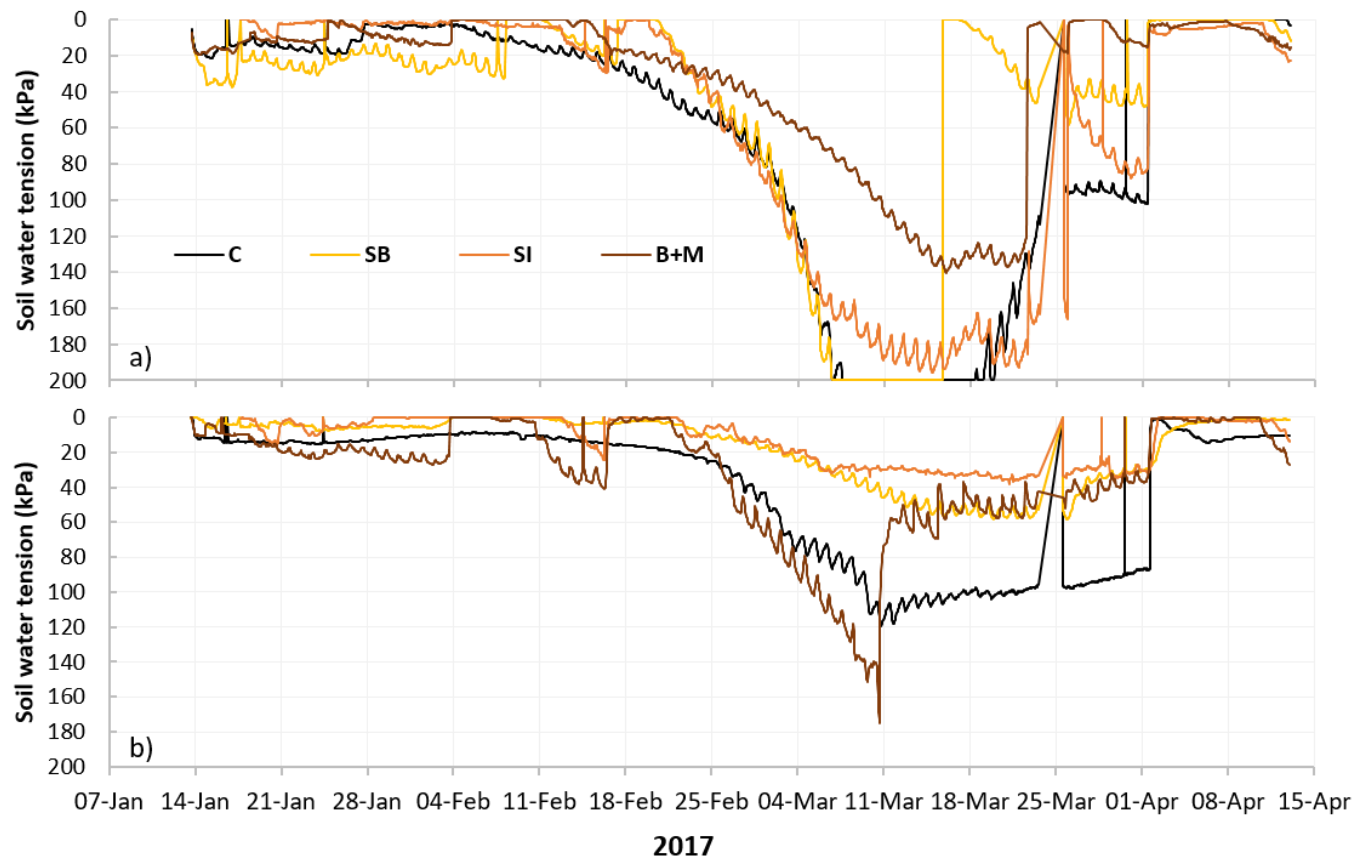

Figure 7. Soil water tension recorded in beds (a) and furrows (b) throughout the season in the four amendment treatments assessed in experiment 2: control (C, unamended), rice straw banded (SB), rice straw incorporated (SI) and manure plus biochar $(\mathrm{B}+\mathrm{M})$.

Root biomass assessment showed that plants from the $B+M$ treatment had the highest root dry mass at harvest (10 April), although no statistically significant differences were found with respect to the other treatments (Table 4). Across all the treatments and at each sampling date, maize roots were typically shallow, between $0.15 \mathrm{~m}$ and $0.30 \mathrm{~m}$ deep, and made up mainly of primary roots. However, some plants produced adventitious roots emanating from the stem. Aboveground biomass was only affected at the last measurement date when it was significantly lower in the two straw treatments (SB and SI) compared with the unamended treatment (Table 4).

At harvest, cob fresh weight in the $C$ and $B+M$ treatments was significantly higher than that obtained in the SI treatment (Table 5). Cob fresh weight was also higher according to fertilizer rate. Treatments $\mathrm{C}$ and $\mathrm{B}+\mathrm{M}$ had the highest $(p<0.05)$ grain yield. None of the organic amendment treatments had any influence on the ratio of grain yield/stem fresh weight. Greater fertilization at sowing (F2) significantly promoted grain yield in relation to the stem fresh weight. The highest aboveground biomass and grain yield were obtained in the $\mathrm{C}$ and $\mathrm{B}+\mathrm{M}$ treatments compared to the treatments amended with rice straw (SB and SI). One explanation for this could be that treatments SB and SI required replanting, causing a delay in development which persisted between these plants and the plants in treatments $\mathrm{C}$ and $\mathrm{B}+\mathrm{M}$ over the duration of the experiment. A second explanation could 
be that amendment in the SB and SI treatments with $10 \mathrm{tha}^{-1}$ of high C:N rice straw may have immobilized plant available nitrogen.

Table 4. Average maize root and shoot production in experiment 2 as a function of organic matter treatment and fertilizer rate.

\begin{tabular}{ccccccccc}
\hline & \multicolumn{3}{c}{ Root Dry Weight (g) } & \multicolumn{4}{c}{ Shoot Dry Weight (g) } \\
\hline & 9 February & 7 March & 27 March & 10 April & 9 February & 7 March & 27 March & 10 April \\
\hline Amendment & $\mathrm{ns}$ & $\mathrm{ns}$ & $\mathrm{ns}$ & $\mathrm{ns}$ & $\mathrm{ns}$ & $\mathrm{ns}$ & $\mathrm{ns}$ & $*$ \\
C & 1.35 & 9.5 & 8.67 & 4.47 & 5.38 & 70.5 & 87 & $108.8 \mathrm{~b}$ \\
SI & 0.85 & 10.5 & 10.17 & 4.67 & 3.02 & 43.17 & 60.83 & $47.9 \mathrm{a}$ \\
SB & 1.13 & 11.33 & 11 & 2.64 & 2.93 & 46.83 & 67.33 & $46.6 \mathrm{a}$ \\
B + M & 1.22 & 10.83 & 11.83 & 8.14 & 3.43 & 71.33 & 107.83 & $79.2 \mathrm{ab}$ \\
Fertilizer & $\mathrm{ns}$ & $\mathrm{ns}$ & $\mathrm{ns}$ & $\mathrm{ns}$ & $\mathrm{ns}$ & $\mathrm{ns}$ & $\mathrm{ns}$ & $\mathrm{ns}$ \\
F1 & 0.84 & 9.25 & 12.25 & 4.78 & 2.59 & 49.33 & 77.92 & 64.86 \\
F2 & 1.43 & 11.83 & 8.58 & 5.17 & 4.79 & 66.58 & 83.58 & 77.9 \\
Amendment & $\mathrm{ns}$ & $\mathrm{ns}$ & $\mathrm{ns}$ & $\mathrm{ns}$ & $\mathrm{ns}$ & $\mathrm{ns}$ & $\mathrm{ns}$ & $\mathrm{ns}$ \\
Fertilizer & & & & & & & &
\end{tabular}

ns denotes not significant and ${ }^{*}$ significant at $p \leq 0.05$. Different letters within a column denote significant differences between treatments.

Table 5. Average fresh weight (FW) of cobs $\left(\mathrm{t} \mathrm{ha}^{-1}\right)$ at harvest, grain yield $\left(\mathrm{t} \mathrm{ha}^{-1}\right)$ and grain yield in relation to the stem fresh weight for each of the amendment (none $(\mathrm{C})$, rice straw buried (SB), rice straw incorporated $(\mathrm{SI})$ and biochar plus manure $(\mathrm{B}+\mathrm{M})$ ) and fertilizer $(\mathrm{F} 1=90 \mathrm{~N} ; 60 \mathrm{P} 2 \mathrm{O} 5 ; 30 \mathrm{~K} 2 \mathrm{O}$; $\mathrm{F} 2=1.5 \mathrm{~F} 1)$ treatments tested in experiment 2 .

\begin{tabular}{cccc}
\hline & Cob FW & Grain Yield & Grain Yield/Stem FW \\
\hline Amendment & $*$ & $*$ & $\mathrm{~ns}$ \\
C & $3.90 \mathrm{~b}$ & $1.94 \mathrm{a}$ & 0.75 \\
SI & $2.23 \mathrm{a}$ & $1.40 \mathrm{~b}$ & 0.53 \\
SB & $2.93 \mathrm{ab}$ & $1.37 \mathrm{~b}$ & 0.56 \\
B + M & $3.82 \mathrm{~b}$ & $1.98 \mathrm{a}$ & 0.62 \\
Fertilizer & $*$ & $*$ & $*$ \\
F1 & 2.64 & $1.45 \mathrm{a}$ & 0.53 \\
F2 & 3.80 & $1.90 \mathrm{~b}$ & 0.70 \\
Amendment $\times$ Fertilizer & $\mathrm{ns}$ & $\mathrm{ns}$ & $\mathrm{ns}$ \\
\hline
\end{tabular}

ns denotes not significant and ${ }^{*}$ significant at $p \leq 0.05$. Different letters within a column denote significant differences between treatments (Tukey).

\subsection{Experiment 3 (PNG 2017-18)}

In experiment 3 conducted on peanut during the 2017/18 dry growing season, GCC of treatments where animal manure had been applied (M and $\mathrm{M}+\mathrm{SB})$ was greater $(p<0.05)$ than in the control treatment during a large part of the season (Figure 8).

This would suggest that although $156 \mathrm{~kg} \mathrm{ha}^{-1}$ of NPK fertilizer was applied in all the treatments at sowing, the incorporated manure provided additional nutrients to the crop that were not available in soil nor supplied in the basal fertilizer. Despite leaf canopy being significantly greater in treatments that received manure compared to the control, statistically significant differences in the aboveground biomass were not observed at any of the four stages of the crop monitored (Table 6). 


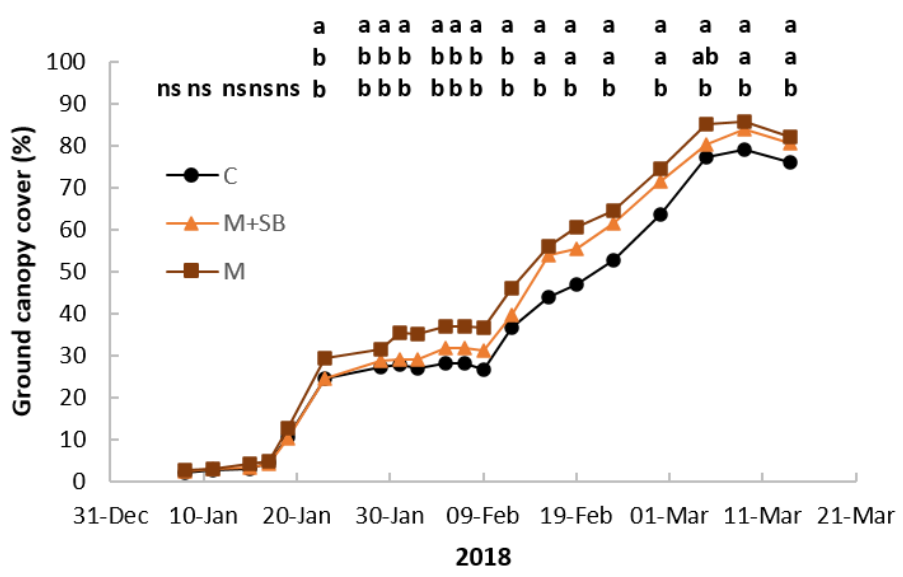

Figure 8. Average percentage of canopy ground cover (GCC) in the treatments assessed in experiment 3: unamended $(\mathrm{C})$, manure $(\mathrm{M})$ and manure plus rice straw banded $(\mathrm{M}+\mathrm{SB})$. Different letters within a measurement date indicate statistically significant differences $(p<0.05)$ between treatments. The order of the letters from top to bottom correspond with the order in which treatments are presented in the legend. "ns" denotes not statistically significant differences.

Table 6. Average aboveground biomass $\left(\mathrm{t} \mathrm{ha}^{-1}\right)$ at the vegetative (30 January 2018), flowering (12 February 2018), pod development (21 March 2018) and maturity (4 April 2018) stage for the control (C), manure (M) and manure plus rice straw $(M+S B)$ amendment treatments tested in the 2017/18 dry season.

\begin{tabular}{ccccc}
\hline & Vegetative & Flowering & Pod Development & Maturity \\
\hline Amendment & $\mathrm{ns}$ & $\mathrm{ns}$ & $\mathrm{ns}$ & $\mathrm{ns}$ \\
$\mathrm{C}$ & 0.53 & 1.17 & 4.72 & 6.52 \\
$\mathrm{M}+\mathrm{SB}$ & 0.73 & 1.77 & 5.94 & 5.91 \\
$\mathrm{M}$ & 0.62 & 1.59 & 5.53 & 6.32 \\
\hline
\end{tabular}

ns denotes not statistically significant differences.

In contrast to experiment 1 , no significant differences were observed between treatments in root length in the $0.05-0.15 \mathrm{~m}$ soil layer in the $2017 / 18$ dry growing season. On average, root length was $230.9 \pm 36.1 \mathrm{~cm}$ at flowering and $281.0 \pm 24.3 \mathrm{~cm}$ at maturity. However, the shoot to root ratio was greater $(p<0.05)$ in the M and M+SB treatments than in the $\mathrm{C}$ treatment (Figure 9).

At harvest, neither pod fresh weight, grain fresh weight, nor grain dry weight of peanut were statistically affected by the organic amendments (Table 7). Water productivity was $\sim 35 \%$ lower in the treatments featuring incorporated manure ( $\mathrm{M}$ and $\mathrm{M}+\mathrm{SB}$ caused by luxuriant growth of leaf canopy (Figure 8 ) due to less biotic stress than the control plants. As a result, plants from the $C$ treatment likely allocated more photosynthates to reproductive development than the $\mathrm{M}$ and $\mathrm{M}+\mathrm{SB}$ treatments and matured earlier.

Table 7. Average values of pod fresh weight $\left(\mathrm{t} \mathrm{ha}^{-1}\right)$, grain fresh weight $\left(\mathrm{t} \mathrm{ha} \mathrm{a}^{-1}\right)$, grain dry weight $\left(\mathrm{t} \mathrm{ha}^{-1}\right)$ and water productivity $\left(\mathrm{kg} \mathrm{mm}^{-1}\right)$ for each of the soil organic amendment treatments: $(\mathrm{C})$ control, (M) manure at $20 \mathrm{t} \mathrm{ha}^{-1}$ and $(\mathrm{M}+\mathrm{SB})$ manure at $20 \mathrm{t} \mathrm{ha}^{-1}$ plus rice straw buried at $5 \mathrm{t} \mathrm{ha}^{-1}$.

\begin{tabular}{ccccc}
\hline & $\begin{array}{c}\text { Pod Fresh } \\
\text { Weight }\end{array}$ & $\begin{array}{c}\text { Grain Fresh } \\
\text { Weight }\end{array}$ & $\begin{array}{c}\text { Grain Dry } \\
\text { Weight }\end{array}$ & $\begin{array}{c}\text { Water } \\
\text { Productivity }\end{array}$ \\
\hline $\begin{array}{c}\text { Organic amendment } \\
\text { treatments }\end{array}$ & $\mathrm{ns}$ & $\mathrm{ns}$ & $\mathrm{ns}$ & $\mathrm{ns}$ \\
$\mathrm{C}$ & 5.30 & 1.69 & 0.72 & 1.45 \\
$\mathrm{M}+\mathrm{SB}$ & 5.20 & 1.23 & 0.47 & 0.94 \\
M & 5.14 & 1.29 & 0.50 & 0.97 \\
\hline
\end{tabular}




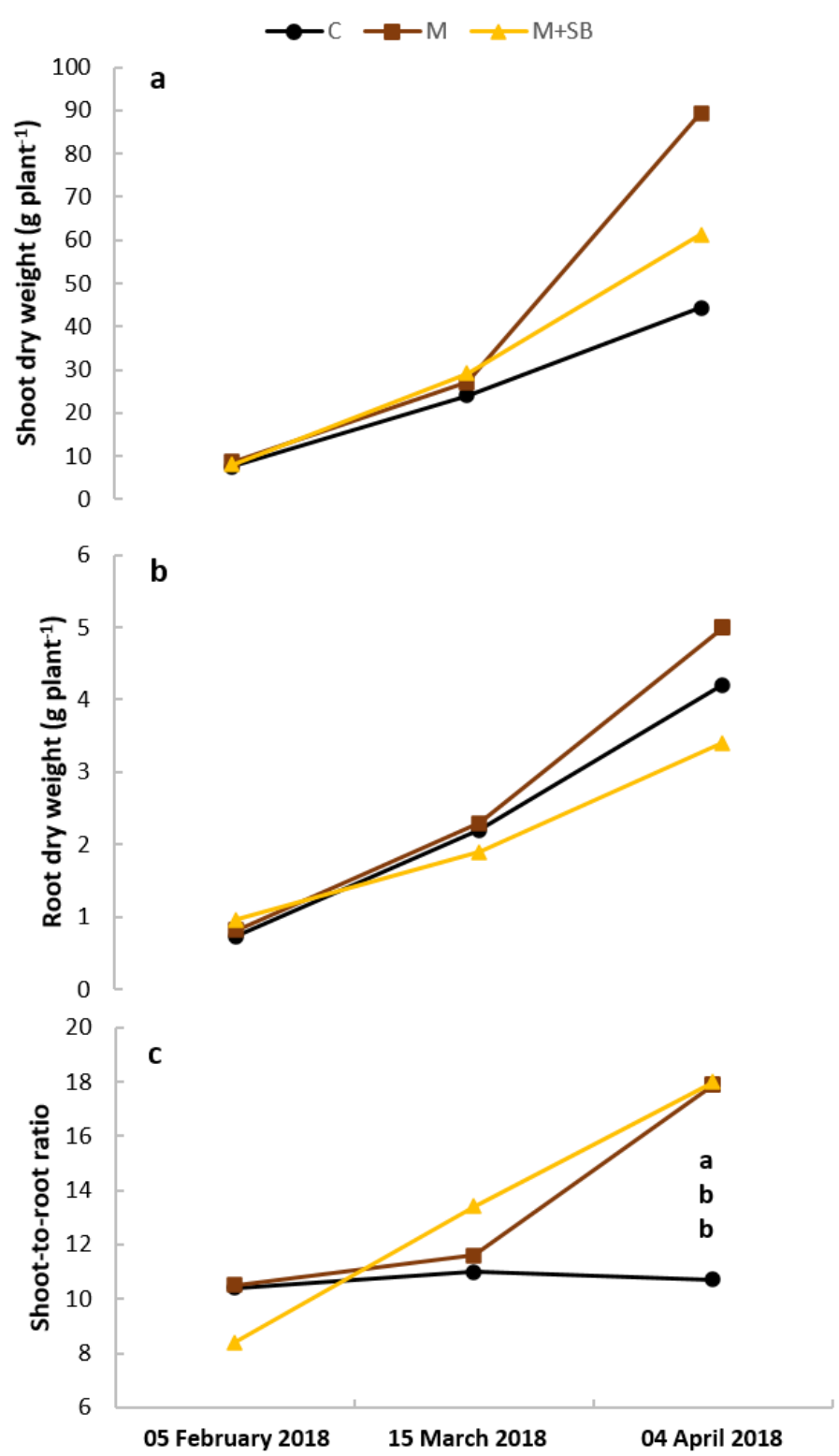

Figure 9. Biomass expressed in dry weight $\left(\mathrm{g} \mathrm{plant}^{-1}\right)$ of shoots (a), roots (b) and shoot-to-root ratio (c) as a function of organic amendments (none $(\mathrm{C})$, manure $(\mathrm{M})$ and manure plus rice straw buried $(\mathrm{M}+\mathrm{SB})$ ) at three crop stages (vegetative/flowering, pod development and maturity) in the 2017/18 dry season. When different letters are shown, these indicate statistically significant differences between treatments. The order of the letters from top to bottom correspond with the order in which treatments are presented in the legend.

\subsection{Experiment 4 (PNG 2017-18)}

Figure 10 illustrates the average soil water tension for each combination of bed architecture and irrigation method tested in the 2017/18 dry growing season at PNG. Three apparent groups can be distinguished in this figure, with the sprinkler irrigation treatments (FB-SI and CB-SI) showing higher soil water tension values (drier soils) at $0.20 \mathrm{~m}$ depth for the entire season than the furrow-irrigated treatments. This higher average soil water tension was ascribed to less water being applied to the crop in the sprinkler-irrigated treatments than in the furrow-irrigated. 


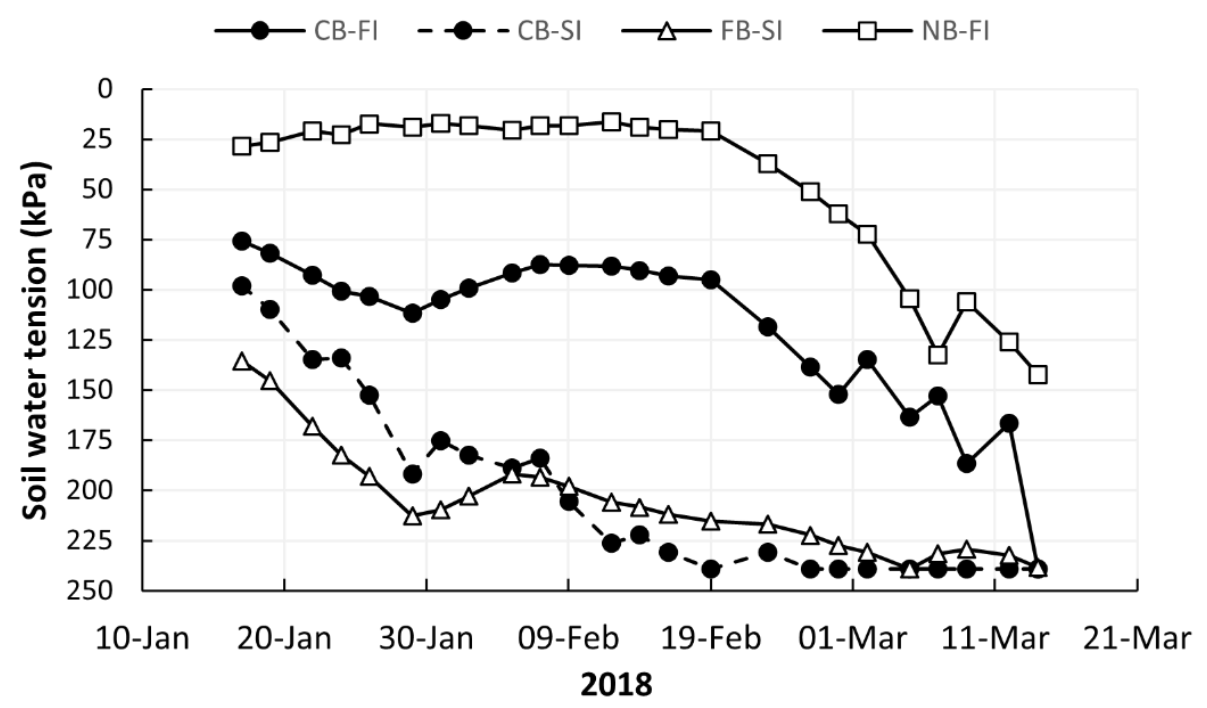

Figure 10. Average soil water tension for each combination of bed architecture and irrigation method tested in the 2017/18 dry growing season: (CB-FI) conventional bed/furrow system with furrow irrigation, (FB-SI) flat bed with sprinkler irrigation, (CB-SI) conventional bed/furrow with sprinkler irrigation and (NB-FI) narrow beds with furrow irrigation.

The furrow-irrigated treatments maintained wetter conditions throughout the growing season with the treatment with the narrow beds (NB-FI) having the lowest soil water tension values (Figure 10). This was mainly due to the differences in bed geometry between the CB-FI and NB-FI treatments. Having twice the number of furrows in the NB-FI treatment compared with the CB-FI as well as narrower beds meant that water could laterally transverse the bed from either side of the seeding row. Therefore, more water was available for the plants in the NB-FI than in the CB-FI treatment.

Measurements of the percentage of GCC showed that for most of the growing season, canopy development of peanut plants in the NB-FI treatment was significantly retarded in comparison to the other treatments (Figure 11). This was more notable during the flowering early pegging period (mid-January to mid-February). However, the canopy of plants from the NB-FI treatment developed further as maturity approached, reaching similar values of GCC at that stage of the crop to those of the other treatments.

Aboveground biomass did not significantly differ between treatments at any sampling date (Table 8). However, in the NB-FI treatment, it appeared delayed compared to the other treatments at the vegetative and flowering stages. This could be due to the sensitivity of pulse crops in general, and peanut in particular, to anoxic soil conditions associated with waterlogged soils [17]. Soil water tension in the NB-FI treatment where narrow beds were investigated remained close to or above field capacity $(\sim 30 \mathrm{kPa})$ for the first six weeks of the growing season (Figure 10), which may have detrimentally affected the early development of plants in this treatment.

Pod and grain weight appeared to be considerably higher in the FB-SI treatment (flat bed with sprinkler irrigation) than in the other treatments, although this result could not be statistically validated (Table 9). No statistically significant differences were detected either among treatments in water productivity. However, considerably higher water productivity was achieved in the two sprinkler-irrigated treatments (FB-SI and CB-SI) than in the furrow-irrigated plots (Table 9). Since $~ 25 \%$ more water was applied in the furrow-irrigated treatments with no effect on yield, the higher apparent water productivity of the FB-SI and CB-SI treatments was most likely due to improved efficiencies as a product of less water losses associated with sprinkler irrigation. As drier soils were observed in the sprinkler-irrigated treatments than in the furrow-irrigated (Figure 10), it can be speculated that the higher level of osmotic stress imposed by the FB-SI and CB-SI treatments due to 
the lower availability of water might have led to greater amount of carbohydrate being channeled into reproductive development and grain production.

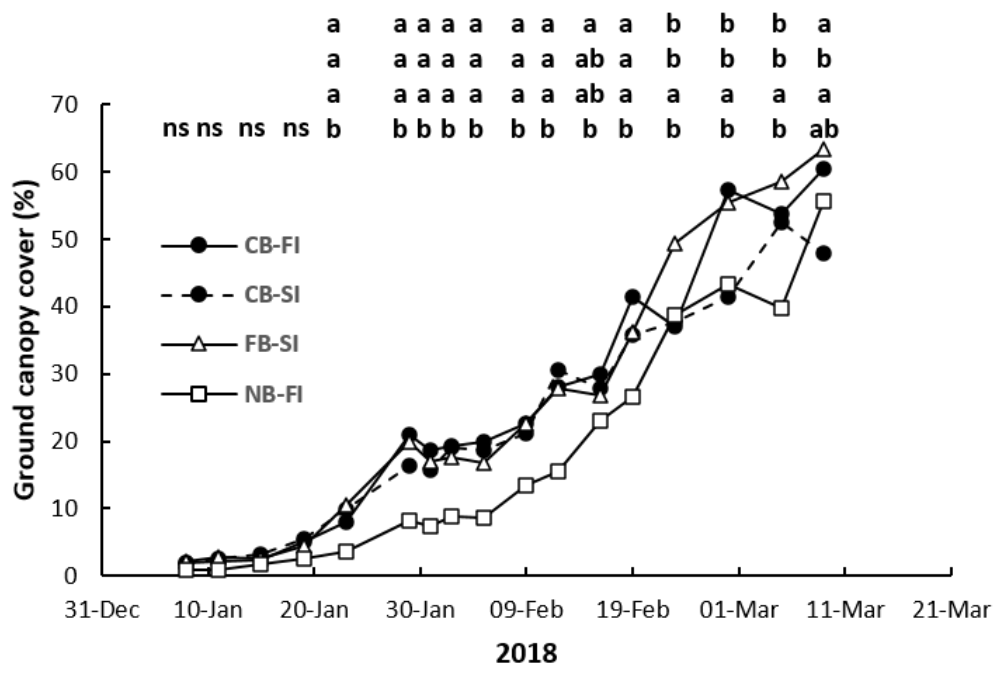

Figure 11. Average percentage of canopy ground cover (GCC) for the treatments assessed in experiment 4: conventional bed/furrow system with furrow irrigation (CB-FI), flat bed with sprinkler irrigation (FB-SI), conventional bed/furrow with sprinkler irrigation (CB-SI) and narrow beds with furrow irrigation (NB-FI). Different letters within a measurement date indicate statistically significant differences $(p<0.05)$ between treatments. The order of the letters from top to bottom correspond with the order in which treatments are presented in the legend. "ns" denotes not statistically significant differences.

Table 8. Average aboveground biomass measured at four stages of the crop in each combination of bed architecture and irrigation method tested in the 2017/18 dry growing season: (CB-FI) conventional bed/furrow system with furrow irrigation, (FB-SI) flat bed with sprinkler irrigation, (CB-SI) conventional bed/furrow with sprinkler irrigation and (NB-FI) narrow beds with furrow irrigation.

\begin{tabular}{ccccc}
\hline & \multicolumn{4}{c}{ Aboveground Biomass (t ha $\mathbf{~}^{\mathbf{1}}$ ) } \\
\hline & Vegetative & Flowering & Pod Development & Maturity \\
\hline Treatment & $\mathrm{ns}$ & $\mathrm{ns}$ & $\mathrm{ns}$ & $\mathrm{ns}$ \\
CB-FI & 0.57 & 1.47 & 3.73 & 4.76 \\
FB-SI & 0.55 & 1.44 & 2.28 & 3.68 \\
CB-SI & 0.48 & 1.25 & 3.72 & 3.18 \\
NB-FI & 0.30 & 0.97 & 4.45 & 4.56 \\
\hline
\end{tabular}

ns denotes not statistically significant differences.

Table 9. Average values of pod fresh weight $\left(\mathrm{tha}^{-1}\right)$, grain dry weight $\left(\mathrm{t} \mathrm{ha}^{-1}\right)$ and water productivity $\left(\mathrm{kg} \mathrm{mm}^{-1}\right)$ for each combination of bed architecture and irrigation method tested in the 2017/18 dry growing season: (I1) conventional bed/furrow system with furrow irrigation, (I2) flat bed with sprinkler irrigation, (I3) conventional bed/furrow with sprinkler irrigation and (I4) narrow beds with furrow irrigation.

\begin{tabular}{cccc}
\hline & Pod Fresh Weight & Grain Dry Weight & Water Productivity \\
\hline Treatments & $\mathrm{ns}$ & $\mathrm{ns}$ & $\mathrm{ns}$ \\
CB-FI & 4.67 & 0.80 & 1.56 \\
FB-SI & 6.05 & 1.12 & 2.83 \\
CB-SI & 4.75 & 0.90 & 2.24 \\
NB-FI & 5.23 & 0.75 & 1.42 \\
\hline
\end{tabular}

ns denotes not statistically significant differences. 


\subsection{Experiment 5 (CARDI 2017/18)}

Despite all plots being watered regularly, drier soils were generally experienced by the over-bed and sprinkler-irrigated treatments rather than the furrow-irrigated plots (Figure 12). The application of rice straw and biochar/manure amendments prior to sowing generally improved soil moisture retention. This effect was more marked in the treatment with rice straw banded and buried at $10 \mathrm{tha}^{-1}$ (SB) for all the replicates within the furrow-irrigated treatment, which had the lowest soil water tension values over the season. This result was consistent with the previous seasons findings at PNG.

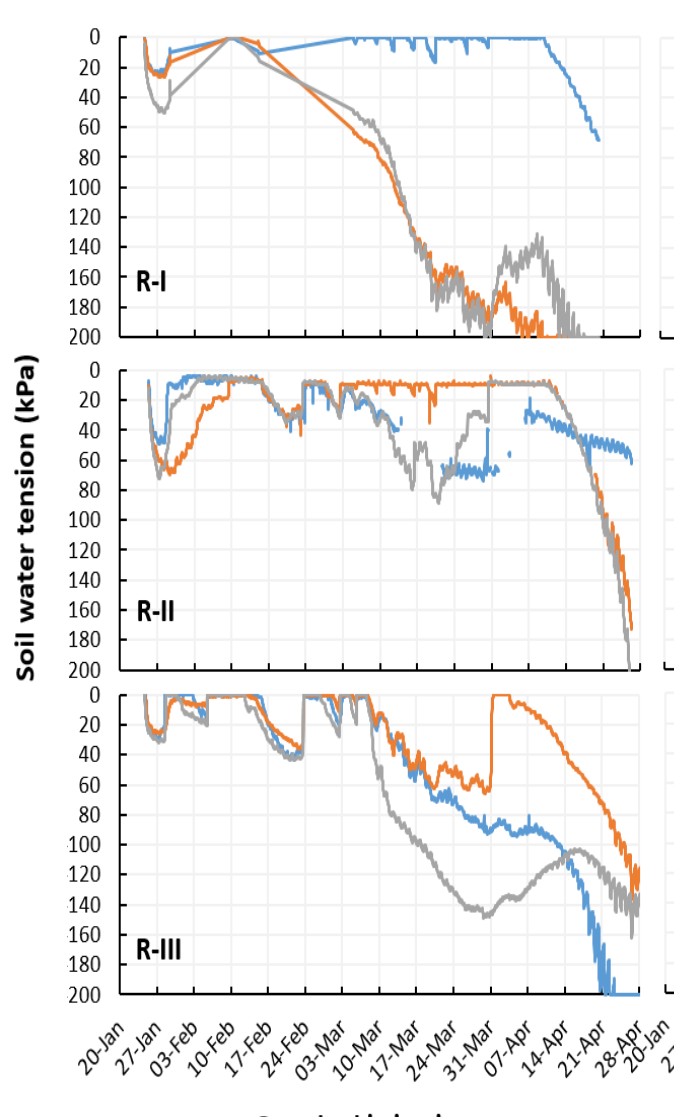

Over-bed irrigation
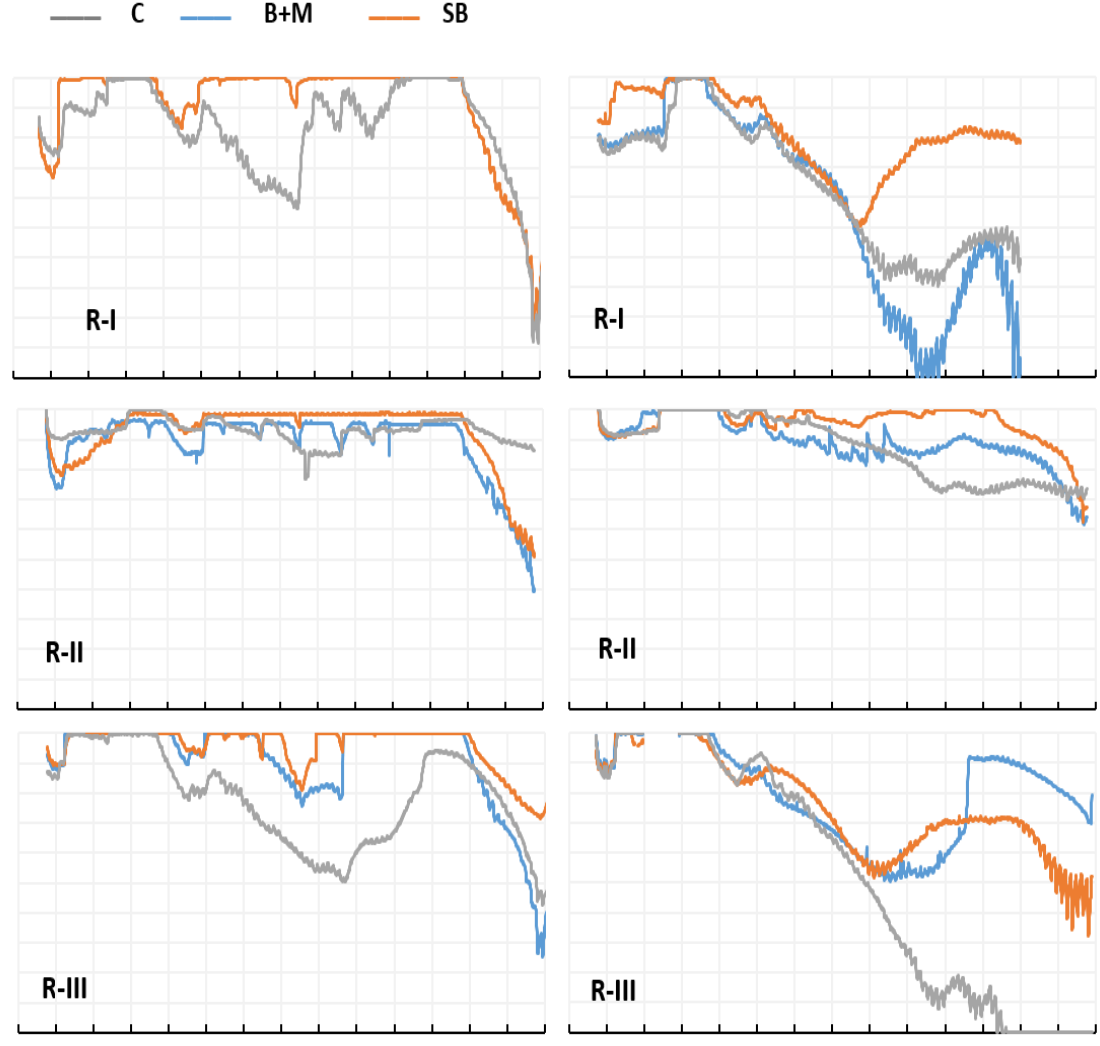

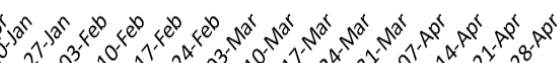

Figure 12. Average soil water tension recorded in each irrigation treatment plot and amendment treatment (control (C), buried rice straw $(S B)$ and biochar plus manure $(B+M)$ ). Note that soil water tension for the $B+M$ amendment plot in the first replicate (R-I) of the furrow-irrigated treatment was not included because the sensor showed anomaly readings for the whole growing season.

Although grain yield in the $\mathrm{B}+\mathrm{M}$ treatment on average was $11 \%$ higher than in the SB treatment, and apparent grain yield appeared lower in the over-bed treatment compared to the sprinkler and furrow-irrigated treatments, there were no statistically significant differences in grain yield among amendment and irrigation treatments (Table 10). Comparison of the water productivity between the sprinkler and furrow irrigation treatments, when the amount of water applied was monitored for each plot individually, showed that sprinkler-irrigated plots had significantly higher water productivity (Table 10). 
Table 10. Average grain yield $\left(\mathrm{t} \mathrm{ha}^{-1}\right)$ and water productivity of maize for the irrigation and amendment (control $(C)$, buried rice straw $(S B)$ and biochar plus manure $(B+M)$ ) treatments and each combination of irrigation and amendment tested in experiment 5 during the 2017/18 dry season.

\begin{tabular}{ccc}
\hline & Grain Dry Weight & Water Productivity \\
\hline Irrigation treatments & $\mathrm{ns}$ & $*$ \\
Furrow irrigation (FI) & 2.07 & 8.76 \\
Over-bed irrigation (OI) & 1.81 & - \\
Sprinkler irrigation (SI) & 2.23 & 10.62 \\
Amendment treatments & $\mathrm{ns}$ & $\mathrm{ns}$ \\
C & 2.00 & 9.67 \\
SB & 1.87 & 9.05 \\
B + M & 2.11 & 10.35 \\
FI-C & $\mathrm{ns}$ & $\mathrm{ns}$ \\
FI-SB & 2.17 & 9.19 \\
FI-B + M & 1.65 & 6.99 \\
OI-C & 2.39 & 10.15 \\
OI-SB & 1.72 & - \\
OI-B + M & 1.63 & - \\
SI-C & 2.08 & - \\
SI-SB & 2.11 & 10.09 \\
SI-B + M & 2.34 & 11.17 \\
Irrigation & 2.23 & 10.63 \\
\hline
\end{tabular}

ns denotes not significant and ${ }^{*}$ significant at $p<0.05$.

Comparing the effect that irrigation treatments had on aboveground biomass, the overbed treatment had significantly $(p<0.05)$ lower aboveground biomass than the sprinkler and furrow-irrigated treatments on 5 March and 29 March 2018 (Figure 13). On the later sampling date, maize plants from the treatment amended with a mix of biochar and manure had the highest aboveground biomass $\left(88.3 \mathrm{~g} \mathrm{plant}^{-1}\right)$ with statistically significant $(p<0.05)$ differences recorded between this and the treatment amended with rice straw (SB; 71.6 g plant $\left.^{-1}\right)$.
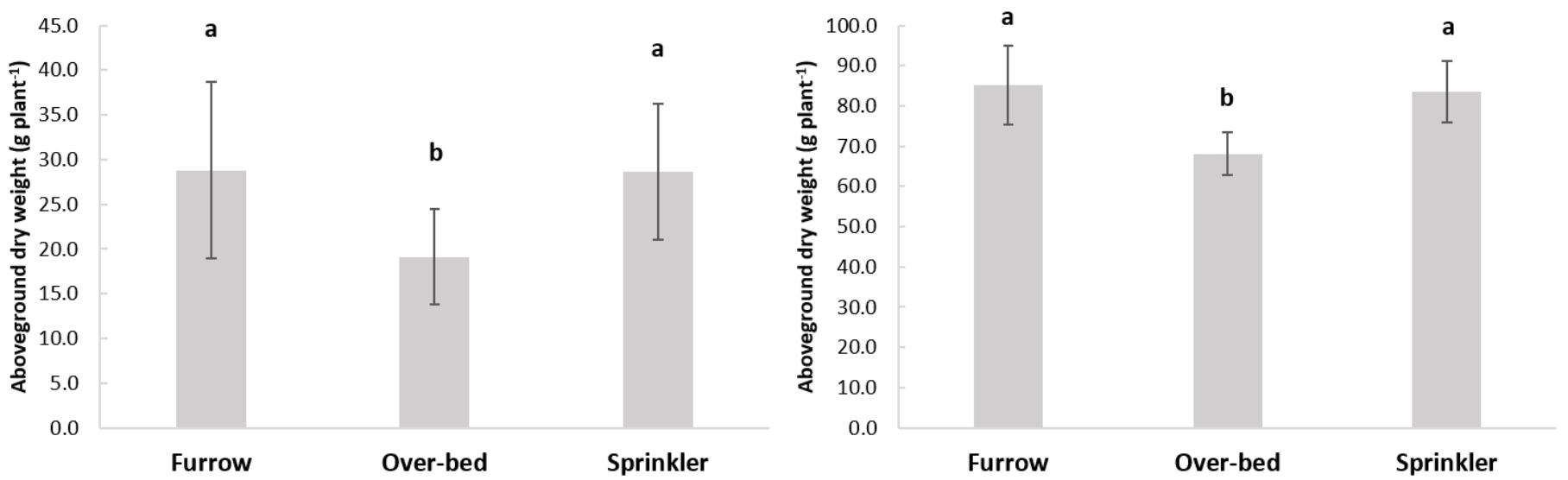

Figure 13. Average aboveground biomass of the irrigation treatments tested in experiment 5 on 5 March (left) and 29 March (right) 2018. Different letters between irrigation treatments indicate statistically significant differences at $p<0.05$.

Assessment of root and shoot biomass within the furrow-irrigated treatment from flowering to harvest did not show any significant difference in root or shoot dry weight, shoot to root ratio, root depth nor roots system width as a function of soil organic amendments (Figure 14). 


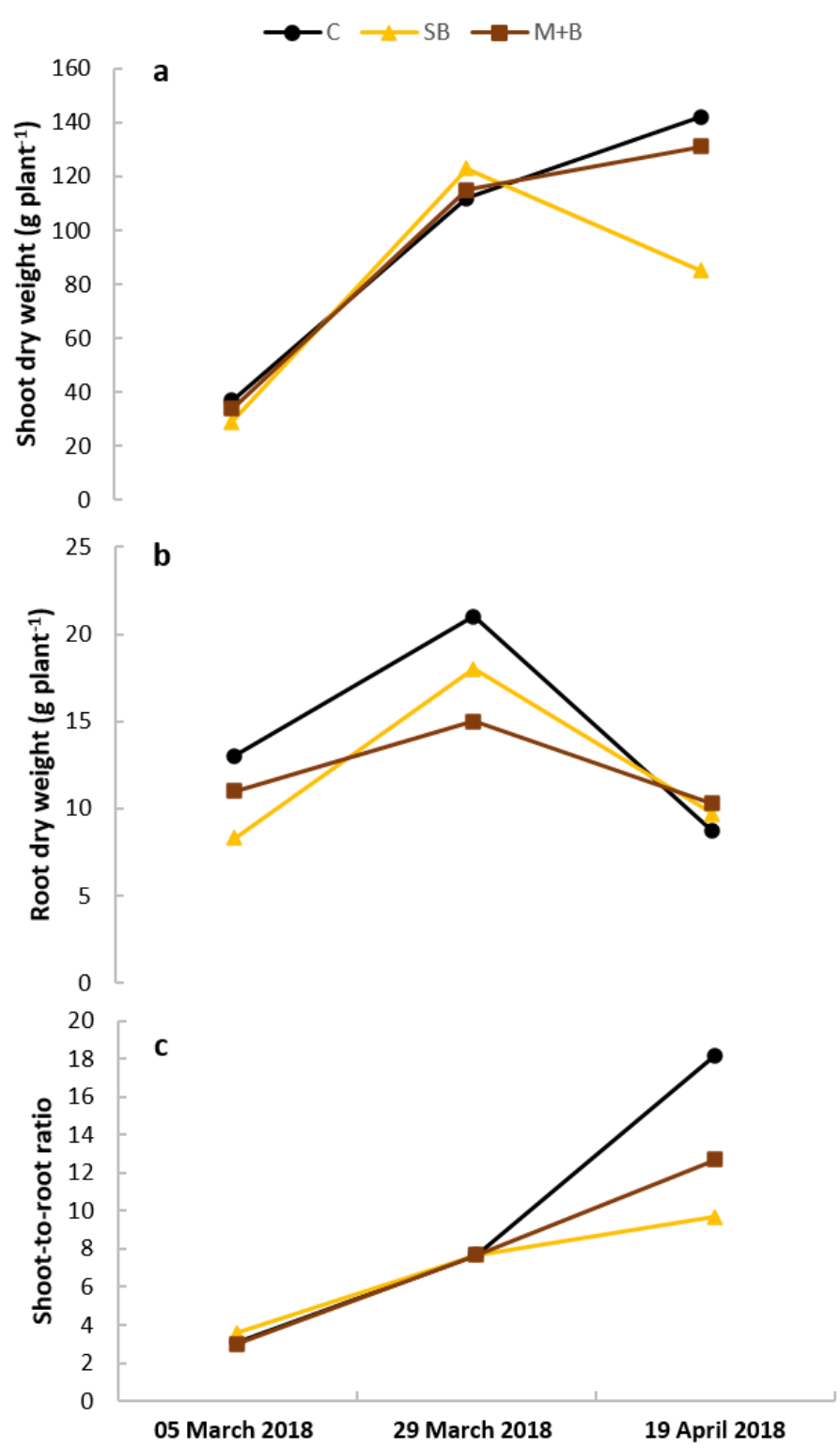

Figure 14. Biomass expressed in dry weight $\left(\mathrm{g} \mathrm{plant}^{-1}\right)$ of shoots $(\mathbf{a})$, roots $(\mathbf{b})$ and shoot-to-root ratio (c) as a function of organic amendments (none (C), manure (M) and manure plus rice straw buried $(\mathrm{M}+\mathrm{SB})$ ) at three crop stages (flowering, cob formation and maturity) within the furrow-irrigated treatment in the $2017 / 18$ dry season.

\subsection{General Discussion}

Soil water tension recorded in this study in experiments 1 and 2 confirmed the constraint reported in Ballester et al. [6] of poor lateral movement of water in rice-growing soils typical of the lowlands of the lower Mekong basin. The lateral movement of water is of importance for crops grown on a "conventional" bed and furrow irrigation system as typically undertaken for dry season crops in both Laos and Cambodia. While strategies such as plant placement in furrows and side of beds could overcome the lack of access of roots to water, these approaches increase waterlogging risk. The current study showed that in bed and furrow systems, improvement of plant access to water can be relatively easily achieved by modifying bed architecture. Narrowing beds increased soil moisture availability for plants (Figure 10) which would likely be of benefit for maize and other non-pulse crops. However, in the case of peanuts, this intervention resulted in the soil becoming too wet, particularly during the vegetative, flowering and early pegging stage, which reduced both vegetative (Figure 11) and reproductive development (Table 8). Delivering more frequent 
but lower volumes of irrigation per event as with sprinkler irrigation would likely be a preferred irrigation technique for peanuts. Further, this practice may potentially lead to saving water (25\% savings were obtained compared with furrow irrigation in experiment 4 ) and boosting water productivity on lowland soils. The availability of nutrients supplied to plants as inorganic fertilizer at sowing could be also compromised by the poor lateral movement of water observed in these soils. However, results obtained in experiment 1 where fertilizer placement was assessed was inconclusive.

In a conventional bed and furrow irrigation system, it was hypothesized that the inclusion of a layer of straw buried below the topsoil would enhance the lateral movement of water into beds and increase soil moisture retention. However, in experiment 2 at CARDI, B + M treatments provided greater soil moisture retention and improved lateral water movement from furrows to the center of beds compared with rice straw. In the case of peanut, it was considered that including a layer of straw could enhance root development, allowing the plant to develop a larger root system and access more water. This effect has been commonly observed where the roots of the current crop exploit stable bio-pores remaining from previous crops [18]. Results in experiment 1 indicated that the presence of rice straw in the layer about $0.05 \mathrm{~m}$ beneath the bed surface promoted the length of lateral roots emanating from the main root at this depth band (Figure 6d). This could be due to a reduced penetration resistance in the top $0.20 \mathrm{~m}$ soil layer observed in the amended treatments in comparison to the control that prevented the soil from forming a thick cemented layer. Results from experiments 1 and 2 also showed that although a below ground layer of straw had in general a positive effect on soil moisture retention compared with a non-amended soil, the consequence of burying high C:N ratio rice residues is likely to cause tie up of $\mathrm{N}$ and $\mathrm{P}$ that may prevent the crop to have access to these nutrients. $\mathrm{N}$ fertilizer immobilization resulting from incorporation of residues with low $\mathrm{N}$ contents and high C:N ratio has been generally reported for rice-based cropping systems in the tropics [19]. Incorporating animal manure to the treatment with rice straw, which could negate any risk of nutrient tie up, was posed in this study as a practice that could overcome this possible issue. Similar strategies integrating the use of amendments, including chemical fertilizers and organic ameliorants, have been reported as beneficial for crops [20]. However, attempts to prove this in experiment 3 failed when root length in the affected zone was unaffected by any treatment and crop yield by peanut growing in soil amended with animal manure was less than that of plants growing in unamended soil. Clay-based soil amendments with manure have been considered by other authors to improve nutrient availability, soil water retention and productivity of crops [12,21,22]. The cost and low availability of clay-based amendments in Cambodia and Laos, however, makes this option less likely to be adopted by smallholders. Simulations of grain production by maize grown in the rice-growing lowlands have shown yields to range from $2.13-1.99 \mathrm{tha}^{-1}$ with an average grain yield of $2.11 \mathrm{tha}^{-1}$ [23]. However, in this study, several treatments examined in experiment 5 produced crops with grain yields well above the average simulated yield for these soils. Treatments leading to actual crop yields exceeding model predictions included those featuring biochar and manure under traditional furrow irrigation $\left(2.39 \mathrm{t} \mathrm{ha}^{-1}\right)$ and rice straw combined with sprinkler irrigation $\left(2.34 \mathrm{tha}^{-1}\right)$. These findings indicated that other crop management interventions exist to enhance maize production on lowland soils across Cambodia and Laos and present an opportunity by which smallholder maize yields may be increased. It seems likely that narrow beds and the addition of stable organic amendments such as rice hull biochar may provide yield enhancement through improved water dynamics as well as enhanced retention of mobile nutrients. Heavy applications of animal manures may contribute to maize production through the increased availability of plant essential nutrients. Further research is needed to verify the mechanism and extent by which amendments of readily available organic sources can augment further maize yields on the extensive areas of these soil types across Cambodia and Laos.

Contrary to the findings in maize, simulations using AquaCrop showed average peanut yields across Champassak province to be $3.76 \mathrm{tha}^{-1}$, and for the three provinces in 
southern Cambodia, $2.69 \mathrm{tha}^{-1}$ [23]. The maximum grain yield attained in peanut in this study (Champassak province) was $1.87 \mathrm{t} \mathrm{ha}^{-1}$. This indicates that the strategies tested here were only producing peanut crops capable of achieving yields $50 \%$ of potential. Previous research on peanut production [6], established crop water requirements and irrigation frequency for peanut crops when growing on these soils. Shorter irrigation intervals had positive effects on yields, largely due to the poor lateral water movement indicated above with more frequent applications of less water tending to "pulse" applied water into the root zone. The gap between actual and potential yields obtained with AquaCrop indicates factors other than water to be restraining actual crop yields. While basal fertilizer application at sowing met crop needs for $\mathrm{N}, \mathrm{P}$ and $\mathrm{K}$, it is likely that other essential nutrients may have been lacking. It was assumed that heavy applications of animal manures may help crops overcome deficiencies in other essential nutrients. However, the inability of animal manures to make up for other nutrient deficiencies indicates either a lack of appropriate nutrients in this material, or a lack of adequate soil microbial activity able to mineralize and release the required nutrients in a plant available form at a rate required by peanuts.

\section{Conclusions}

In this study, the use of organic interventions, bed architecture and irrigation methods in rice-growing lowland soils to overcome the poor lateral movement of water into beds observed in dry-season crops grown in a bed/furrow system was assessed in peanut and maize crops.

Narrowing beds increased soil moisture availability for plants. Although this strategy was shown not to be appropriate for peanut, it could be of interest in non-pulse crops that could have a market space in Cambodia and Laos. For peanut production, sprinkler irrigation would be recommendable to prevent the soil to remain near saturation for long periods and to improve water productivity.

Incorporation of rice straw into beds could be other strategy to be considered to enhance soil moisture retention and root development. This strategy, however, may prevent the crop from having access to nutrients, and its use should be accompanied by a source of nutrients that could negate any risk of nutrient tie up. In this study, however, incorporation of manure along with the rice straw did not have a positive effect on root development and crop performance.

The study showed that the addition of organic amendments such as biochar and manure may enhance maize production on lowland soils above the average simulated yield for these soils. These findings present opportunities to enhance maize production on lowland soils across Cambodia and Laos. The contrary, however, was observed for peanut, which indicates that factors other than water detrimentally affect crop yields. This could be related to a lack of essential nutrients other than N, P and K. Further research is needed to find management strategies that could bridge the identified gap between potential and actual peanut yields.

Author Contributions: Conceptualization, P.E., C.V., P.S., V.S. (Vorachith Sihathep), V.S. (Vang Seng), J.M., W.Q. and J.H.; data acquisition, C.V., P.E., V.S. (Vorachith Sihathep), V.L., V.T. and A.M.; data analysis, C.B., A.M., C.V. and P.E.; writing—original draft preparation, C.B. and P.E.; writing-review and editing C.B., P.E., W.Q. and J.H.; funding acquisition, P.E., J.H., V.S. (Vang Seng), T.I. and C.O. All authors have read and agreed to the published version of the manuscript.

Funding: This research was funded by the Australian Centre for International Agricultural Research (ACIAR), grant number SMCN/2012/071.

Acknowledgments: The authors would like to thank all project staff as well as students from the Institute of Technology Cambodia who participated in this project. The authors too would like to acknowledge the assistance made by 4th year Agricultural Science students from Charles Sturt University, Harriet Brickhill, Jillian Lyall, Grace Rogers and Thom Jeffery (Lao), Cheyenne Gibbs and Alistair Dart (Cambodia) who undertook internships in country funded by an Australian Government 
New Colombo Plan Mobility Grant 'Ground to Plate—farming systems in Cambodia/Laos' and assisted with research and data collection at both PNG (Lao PDR) and CARDI (Cambodia).

Conflicts of Interest: The authors declare no conflict of interest.

$\begin{array}{ll}\text { Abbreviations } \\ \text { PNG } & \text { Phone Ngam Rice Research Centre } \\ \text { CARDI } & \text { Cambodian Agricultural Research and Development Institute } \\ \text { C } & \text { Control } \\ \text { SB } & \text { Rice straw buried } \\ \text { M } & \text { Cow and goat manure (50:50) } \\ \text { SI } & \text { Rice straw incorporated } \\ \text { B + M } & \text { Rice straw biochar plus cow manure } \\ \text { M + SB } & \text { Cow manure plus rice straw buried } \\ \text { CB-FI } & \text { Conventional bed and furrow-irrigated } \\ \text { FB-SI } & \text { Flat bed and hand sprinkler-irrigated } \\ \text { CB-SI } & \text { Conventional bed and hand sprinkler-irrigated } \\ \text { NB-FI } & \text { Narrow bed and furrow-irrigated } \\ \text { DAP } & \text { Di-ammonium phosphate } \\ \text { KCl } & \text { Potassium chloride }\end{array}$

\section{References}

1. Yamauchi, K. Climate change impacts on agriculture and irrigation in the lower mekong basin. Paddy Water Environ. 2014, 12, 227-240. [CrossRef]

2. Comission, M.R. State of the Basin Report 2010; Mekong River Comission: Vientiane, Laos, 2010.

3. Fukai, S.; Ouk, M. Increased productivity of rainfed lowland rice cropping systems of the mekong region. Crop Pasture Sci. 2012, 63, 944-973. [CrossRef]

4. Bell, R.W.S. Rainfed lowland rice-growing soils of Cambodia, Laos, and North-east Thailand. In Proceedings of the CARDI International Conference on Research on Water in Agricultural Production in Asia for the 21st Century, Phnom Penh, Cambodia, 25-28 November 2003; pp. 161-173.

5. White, P.E. The Soils Used for rice Production in Cambodia: A Manual for Their Identification and Management; White, P.F., Oberthür, T., Sovuthy, P., Eds.; Cambodia-IRRI-Australia Project (CIAP): Phnom Penh, Laos, 1997.

6. Ballester, C.; Vote, C.; Hornbuckle, J.; Inthavong, T.; Lim, V.; Oeurng, C.; Quayle, W.; Seng, V.; Sengxua, P.; Sihathep, V.; et al. Effects of frequency of irrigation on dry-season furrow-irrigated maize and peanut production in the rice-growing lowlands of the lower mekong basin. Agriculture 2019, 9, 128. [CrossRef]

7. Lal, R. Enhancing crop yields in the developing countries through restoration of the soil organic carbon pool in agricultural lands. Land Degrad. Dev. 2006, 17, 197-209. [CrossRef]

8. Diacono, M.; Montemurro, F. Long-term effects of organic amendments on soil fertility. In Sustainable Agriculture Volume 2; Lichtfouse, E., Hamelin, M., Navarrete, M., Debaeke, P., Eds.; Springer: Dordrecht, The Netherlands, 2011; pp. 761-786.

9. Li, Z.; Schneider, R.L.; Morreale, S.J.; Xie, Y.; Li, C.; Li, J. Woody organic amendments for retaining soil water, improving soil properties and enhancing plant growth in desertified soils of ningxia, China. Geoderma 2018, 310, 143-152. [CrossRef]

10. Sitthaphanit, S.; Bell, R.W.; Limpinuntana, V. Effect of clay amendments on nitrogen leaching and forms in a sandy soil. In Proceedings of the 19th World Congress of Soil Science, Brisbane, Australia, 1-6 August 2010; pp. 107-110.

11. Uzoma, K.C.; Inoue, M.; Andry, H.; Fujimaki, H.; Zahoor, A.; Nishihara, E. Effect of cow manure biochar on maize productivity under sandy soil condition. Soil Use Manag. 2011, 27, 205-212. [CrossRef]

12. Mekuria, W.; Noble, A.; Sengtaheuanghoung, O.; Hoanh, C.T.; Bossio, D.; Sipaseuth, N.; McCartney, M.; Langan, S. Organic and clay-based soil amendments increase maize yield, total nutrient uptake, and soil properties in lao pdr. Agroecol. Sustain. Food Syst. 2014, 38, 936-961. [CrossRef]

13. FAO. FAOSTAT. Available online: http://www.fao.org/faostat/en/\#data/QI (accessed on 2 November 2020).

14. Comission, M.R. Soil Map of the Lower Mekong Basin. MRC Secretariat, Ed.; Mekong River Comission: Vientiane, Laos, 2002.

15. Patrignani, A.; Ochsner, T.E. Canopeo: A powerful new tool for measuring fractional green canopy cover. Agron. J. 2015, 107, 2312-2320. [CrossRef]

16. Matsuo, K.; Ae, N.; Vorachit, S.; Thadavon, S. Present soil chemical status and constraints for rice-based cropping systems in vientiane plain and neighboring areas, lao pdr au-Matsuo, kazuyuki. Plant Prod. Sci. 2015, 18, 314-322. [CrossRef]

17. GRDC. Grownote Peanuts; Grains Research and Development Corporation: Barton, Australia, 2017.

18. Landl, M.; Schnepf, A.; Uteau, D.; Peth, S.; Athmann, M.; Kautz, T.; Perkons, U.; Vereecken, H.; Vanderborght, J. Modeling the impact of biopores on root growth and root water uptake. Vadose Zone J. 2019, 18, 180196. [CrossRef] 
19. Yadvinder, S.; Bijay, S.; Timsina, J. Crop residue management for nutrient cycling and improving soil productivity in rice-based cropping systems in the tropics. In Advances in Agronomy; Academic Press: Cambridge, MA, USA, 2005; Volume 85, pp. 269-407.

20. Noble, A.D.; Ruaysoongnern, S.; de Vries, F.P.; Hartmann, C.; Webb, M. Enhancing the agronomic productivity of degraded soils in north-east thailand through clay-based interventions. Water Agric. 2004, 116, 147-160.

21. Mekuria, W.; Getnet, K.; Noble, A.; Hoanh, C.T.; McCartney, M.; Langan, S. Economic valuation of organic and clay-based soil amendments in small-scale agriculture in lao pdr. Field Crops Res. 2013, 149, 379-389. [CrossRef]

22. Mekuria, W.; Sengtaheuanghoung, O.; Hoanh, C.T.; Noble, A. Economic contribution and the potential use of wood charcoal for soil restoration: A case study of village-based charcoal production in central laos. Int. J. Sistain. Dev. World Ecol. 2012, 19, 415-425. [CrossRef]

23. Eberbach, P.; Hornbuckle, J.; Ballester-Lurbe, C. Improving Water and Nutrient Management to Enable Double Cropping in the Rice Growing Lowlands of Lao PDR and Cambodia; FR2020-028 Canberra ACT 2601; Australian Government: Canberra, Australia, 2020. 